\title{
Spatial and temporal appraisal of drought jeopardy over the Gangetic West Bengal, eastern India
}

\author{
Krishna Gopal Ghosh(D)
}

\begin{abstract}
Background: In the contemporary era of global warming there is growing need to detail geographical variations of drought risk so as to investigate the impact of climate change in the densely populated agricultural tract of Gangetic West Bengal (GWB), eastern India. In aim to assess drought jeopardy at the regional scale, the present study deals with temporal trend and spatial pattern of drought during the last century over GWB. Standardized Precipitation Index (SPI) has been used to detail geographical variations of drought intensity, duration, frequency etc. at multiple time steps. Non-parametric Mann-Kendall test and Sen's slope estimator are used to detect the trends and trends slope. In addition, the article focuses on developing a Composite Drought Risk Index (CDRI) integrating 10 parameters pertaining to drought exposure to detect which regions are most exposed to drought.

Results: The results portray a very diverse but consistent picture. The last century exhibits some consecutive deficit and surplus phases and after 1950s the extremity of surplus and deficit as well as drought duration have increased substantially. The impact of drought is expected to be rigorous at or adjacent areas of the western degraded plateau, particularly the northern Rarh and moribund delta where the drought intensities tend to increase while the rainfall as well as recurrence interval of drought tend to decrease.

Conclusions: In a nutshell, this work provides evidences demonstrating the extension and intensification of aridity in the northern Rarh plain and Moribund delta. Such altered hydrolo-meteorological system hence calls for review of the agricultural practices and water use in GWB. The CDRI provides a means of obtaining a broad overview of drought risk and supposed to allow decision makers more in-depth investigation.
\end{abstract}

Keywords: Standardized precipitation index (SPI), Drought intensity, Drought duration, Drought frequency, Threshold rainfall, Drought risk

\section{Introduction}

Water scarcity is one of the major threats to contemporary water resources management (Bates et al. 2008). Water paucity is being further compounded by discrepancy in precipitation and rise of temperature because of climate change (IPCC 2013). According to an estimation, in India, the total water demand will increase up to $32 \%$ by 2050 (Amarasinghe et al. 2007) and 1/2 of the cultivated area will continue to be under rain-fed farming even after the full irrigation potential of the country is utilized (CRIDA 2007). Furthermore, fresh water availability and rain-fed farming

Correspondence: k.g.ghosh@india.com

Department of Geography, Presidency University, Kolkata, West Bengal 700073, India

(c) The Author(s). 2019 Open Access This article is distributed under the terms of the Creative Commons Attribution 4.0 International License (http://creativecommons.org/licenses/by/4.0/), which permits unrestricted use, distribution, and reproduction in any medium, provided you give appropriate credit to the original author(s) and the source, provide a link to the Creative Commons license, and indicate if changes were made. are reported to be threatened through increased risk to droughts. The water requirement in India by 2050 will be in the order of $1450 \mathrm{~km}^{3}$, which is significantly higher than the estimated water resources of $1122 \mathrm{~km}^{3}$ per year. Therefore to meet the requirement, it is necessary to harness additional $950 \mathrm{~km}^{3}$ per year over the present availability of $500 \mathrm{~km}^{3}$ per year (Gupta and Deshpande 2004).

Drought is one of the most common climatic extremes (NRC 2010) that affects the majority of people across the globe (Wilhite 2003). Draught events are reported to be strengthening in this era of global warming (Burke et al. 2006; Tsubo et al. 2009). Since 1970s there is a drying trend in the northern latitudes (Trenberth et al. 2007, 2014), particularly, in the tropics and subtropics (IPCC 2007) and consistent shifts in drought regimes (Dai \\ Springer Open}


2011). In India as much as $50 \%$ area is considered as severely drought prone (Kamble et al. 2010) and climate change is expected to change the existing drought vulnerability profile of the country (O'Brien et al. 2004). In the past century frequency of hot days and multiple day heat waves have increased by far (Lal 2003). As per CRED (2016) reports, drought events (1900-2016) in India have affected nearly 1391 million people. Increase intensity and frequency of drought events in future are likely to threaten the water resources and food security of the country. Therefore, identification of the drought risk areas is crucial particularly for the monsoon based agro-economy of India.

Gangetic West Bengal (GWB) is one of the leading agricultural hubs of eastern India. According to IPCC report (2007) this region expected to receive less rain and likely to experience $0.5-1{ }^{\circ} \mathrm{C}$ rise in average temperature during $2020-2029$ and $3.5-4.5^{\circ} \mathrm{C}$ rise in $2030-2099$. Over the last a few years, the impact of climate change has felt severely in this counterpart (INCCA 2010). Late monsoon arrival has been observed with less intensity, duration of summer has become longer and drought has become more frequent (WBSAPCC 2010; Mishra 2010; RPAPCC 2012; Ghosh 2016, 2018). The GWB has less experience of coping with droughts, in comparison to floods, resulting in poor preparedness. The problems have been further compounded by growing population, lack of water resource development initiatives and adoption of water intensive commercial crops. Under such situations, for the rational management of water resources of this region, spatio-temporal appraisal of drought could be a good attempt.

Global concern for climate change has led to pay significant attention for analyzing drought in quantitative forms. Over the years, a number of indices have been in use for drought portrayal Keyantash and Dracup (2002), Mishra and Singh (2010, 2011), Zargar et al. (2011) have reviewed dozens of such indices. However, drought indices based on only rainfall data are simple to compute and found to perform better (Oladipo 1985). Among the commonly used indices that use rainfall data, Standardized Precipitation Index, SPI (Mckee et al. 1993) is frequently applied worldwide (Hosseinizadeh et al. 2015) for drought assessment. The World Meteorological Organization (WMO) considered SPI as a standard drought monitoring index (Hayes et al. 2011). It is one of the two indices (other being Aridity Anomaly Index) used by the Indian Meteorological Department (IMD). Since SPI is standardized and has a probabilistic interpretation (Guttman 1998), the present study is going to utilize this.

There are many studies on the general characteristic of droughts over India (Parthasarathy et al. 1987; Pai et al. 2011; Mallya et al. 2016), case studies on the specific drought years (Sikka 2003; Francis and Gadgil 2010) and region (Mishra and Nagarajan 2011; Rachchh and Bhatt 2014; Thomas et al. 2015). So far there have been little attempts (viz., Chanda and Dhar 1975; Kar et al. 2012; Palchaudhuri and Biswas 2013) to assess drought for the present study area. Therefore, we need to improve our knowledge on drought jeopardy in this densely populated tract with vast agricultural expanse. However, drought characterization, which enables operations such as drought early warning (Kogan 2000) and drought risk analysis, that allows improved preparation and contingency planning (Hayes et al. 2004) is needful for the holistic appraisal of drought for a region. From these perspectives, the present study ensue two basic objectives-first: to examine the spatio-temporal nature of drought over GWB and second: to assess drought risk integrating multiple relevant parameters.

\section{Geographical personalities of the Gangetic West Bengal}

West Bengal, a state on the eastern bottleneck of India, has its intrinsic climatic diversity primarily due to the vast physiographic assortment stretching from the eastern Himalaya in the North to coastal regions in the South, amid regions of plateau highlands and Ganges delta intervening in between. Indian Meteorological Department (IMD) has divided this state into two meteorological sub-divisions- the Sub-Himalayan West Bengal \& Sikkim and Gangetic West Bengal (GWB). Present study focuses on the GWB, the southern half of West Bengal below Farakka barrage located from $21^{\circ} 32^{\prime} 23.69^{\prime \prime}$ to $24^{\circ}$ $51^{\prime} 20.5^{\prime \prime}$ North latitudes and $85^{\circ} 49^{\prime} 49.39^{\prime \prime}$ to $89^{\circ} 8^{\prime}$ 48.76" East longitudes (Fig. 1) with a total area of $63,879 \mathrm{~km}^{2}$, elevation ranges from virtually 0 to $677 \mathrm{~m}$ above MSL and is surrounded by Jharkhand state in the West, Odisha state in the Southwest and Bangladesh in the East.

It is a typical region considered from physiographical, soil, drainage and climatic point of view. Physiographically, it forms the transitional zone between the Chhotanagpur plateau in the West to the plains of the Ganga-Brahmaputra delta in the southern and eastern section. Land slopes from West to South-East and from North to South. Spread over eight major physiographic divisions (Fig. 1) the GWB has been delineated into 71 mapping units (Haldar et al. 1992), red and gravely, lateritic, Gangetic alluvial, Vindhya alluvial and coastal alluvial soil characterized the soil-scape. River Ganges by the name Bhagirathi enters this region in the northern extreme, flows in a south-easterly direction and empties its water into the Bay of Bengal (Biswas 2001) discharge 


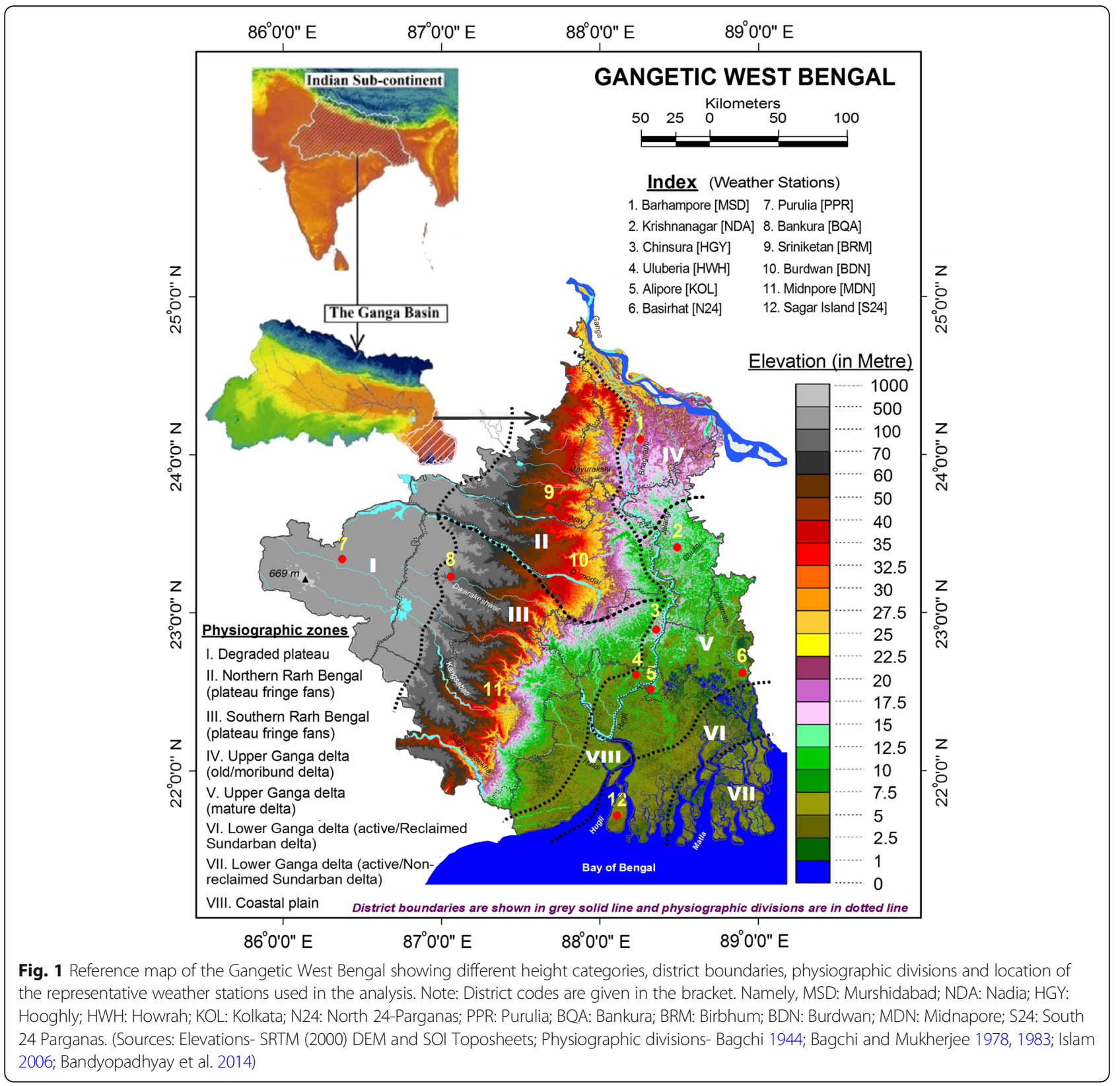

of which is primarily fluctuate in response to the seasonal climatic rhythm.

The climate is typical, sub-tropical monsoon type having four main seasons namely- Cold-weather/Winter (Jan-Feb); Hot-weather/Summer/Pre-Monsoon (MarMay); Southwest Monsoon/rainy (Jun-Sep) and a short Post-Monsoon/retreating Southwest Monsoon/autumn (Oct-Dec). Out of the total annual rainfall, about 70$80 \%$ occurs during the monsoon and contributing as much as $90 \%$ to the discharge of the rivers. In early summer brief squalls and thunderstorms (Kalbaisakhi) strike the region (Roy and Mukhopadhyay 2012). In this period the western highlands experience excessive dry condition and suffer from frequent heat wave when the maximum temperature goes up to $45^{\circ} \mathrm{C}$ or even beyond.

\section{Background of the study}

This densely populated tract (about 1051 person $\mathrm{km}^{-2}$ ) which impart with a vast expanses of fertile alluvial soil is the hub of rice and jute cultivation as well as (freshwater) fish production. The Net Shown Area, Gross Cropped Area and Cropping Intensity count about 61\%; 112 and 184\% respectively (AD-GoWB 2009). According to 2011 census the state's population of $72 \%$ resides in rural areas and $88 \%$ of the total land holdings belong to marginal and small farmers (AD-GoWB 2009). 
Agriculture in this region is mainly rain-fed and rainfall extremities put heavy stress on not merely agricultural activities but other economic activities also. As much as $40 \%$ area of GWB is susceptible to floods (DoIW-GoWB 2014) and 16\% area is drought-prone (WBPCB 2009). Average water demand in this tract varies from about 0.9 to $1.8 \mathrm{Mm}^{3} \mathrm{~km}^{-2}$ in compare to the average water availability of 0.5 to $1.0 \mathrm{Mm}^{3} \mathrm{~km}^{-2}$ (Bandyopadhyay et al. 2014). All these demonstrate the sensitiveness to rainfall availability on socio-economic fabric of this region.

Study of Ghosh (2018) highlighted a considerable decrease of rainfall in early monsoonal month of June and mid monsoonal month of August for GWB. It signifies that early monsoonal rainfall is declining and mid-season/intermittent dry spells/drought respectively. A majority of the widely accepted climatic model based studies tend to suggest delayed onset for the south Asian monsoon in the eastern part of tropical Indian Ocean (Dong et al. 2016). If monsoon arrives lately, duration of summer will become longer and drought event will become more frequent. Ten districts of GWB received less than $33 \%$ of the normal monsoon rainfall during the year 2010, which severely affected the sowing of paddy and were declared drought-hit (MoSPI-GoWB 2012). In the northern Rarh and moribund delta there are significantly decreasing trend of rainfall for annual and monsoonal series (Fig. 2a and b). It indicates strengthening of drier condition of these two regions. Study of Ghosh (2016) confirmed that, in the Birbhum district of the northern Rarh region there is a considerable decrease in monsoonal rainfall and increase in draught events in recent decades. Nath et al. (2008), WBSAPCC (2010), RPAPCC (2012) etc. have addressed some means for drought management in the state, regional and local levels. However, an essential component of drought risk management requires situational appraisal and the present paper attempts to do this.

\section{Materials and methods}

\section{Data sources}

Annual and monthly datasets for 11 climatic variables from 1901 to 2002 and 2004-2010 for almost each districts of India comprising a network of $>300$ meteorological stations over 30 meteorological subdivisions around the country is available from https://www.indiawaterportal.org/met_data/. However, in this study only continuous time series rainfall data belonging to 12 meteorological stations (one representative station per district) of GWB (Fig. 1) for the period of 1901-2002 have been used for the reason that data for 2003 is not

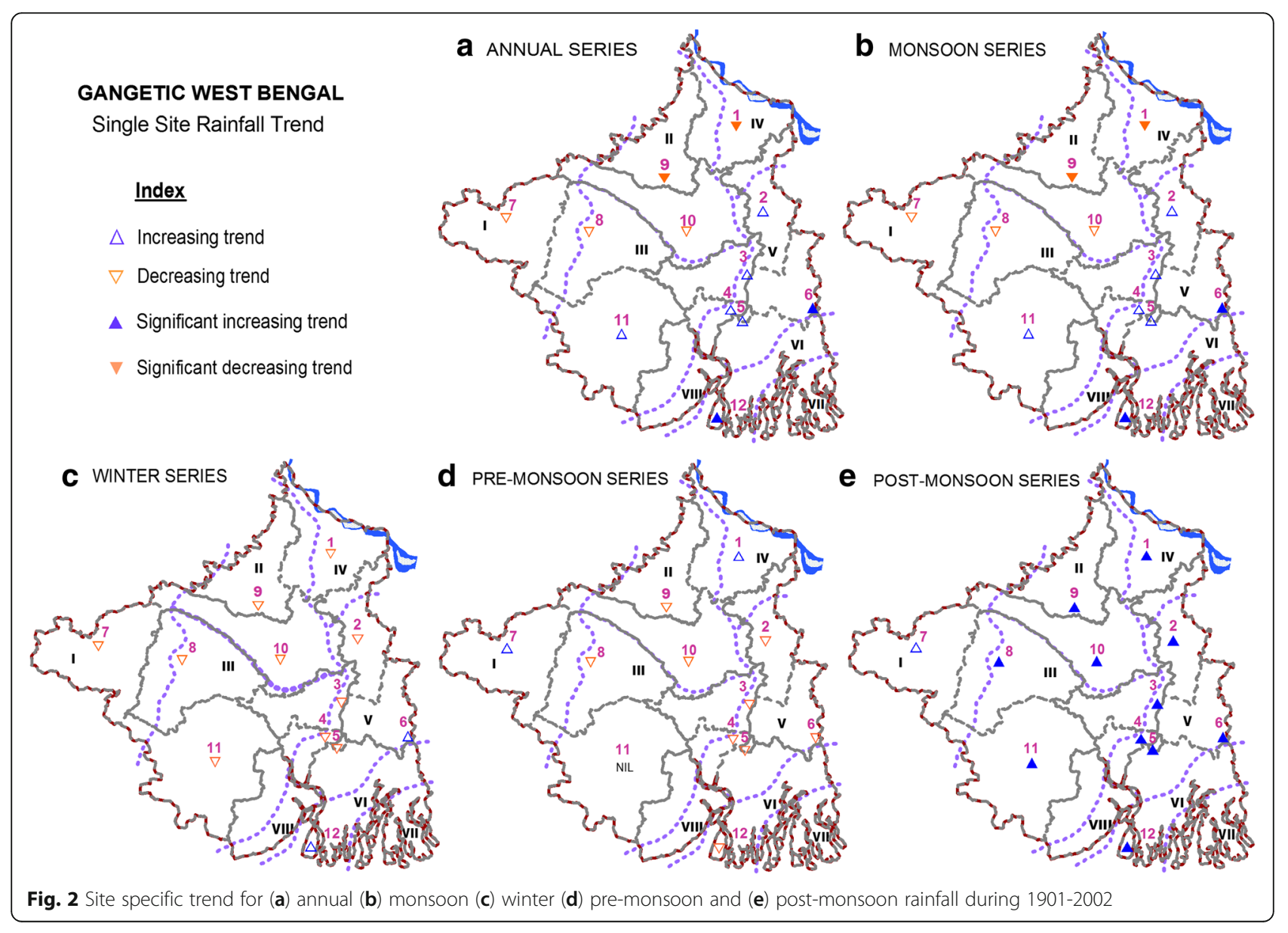


available. There are however, about 20 meteorological stations over GWB but long term data for the desired period are not available for rest of the stations. The IMD strictly controlled data quality and missing data values were substituted with average values.

\section{Drought evaluation parameters}

Deviation (deficit) of rainfall from normal over a geographic area during a period is broadly accepted as drought. Wilhite and Glantz (1985) analyzed more than 150 drought definitions and broadly grouped those under four categories- meteorological, agricultural, hydrological and socio-economic. Meteorological drought originates from a deficiency of precipitation and other types of drought cascade from this deficiency. Dracup et al. (1980) noticed several drought characteristics in all drought studies: intensity, duration, magnitude and frequency. In the present slot, the author has tried to capture all of these dimensions along with the trend and some others variables.

\section{Standardized precipitation index (SPI)}

SPI, developed by McKee et al. $(1993,1995)$ is a simple but flexible tool where probability of observed precipitation has been transformed into an index to monitor drought at multiple time scales. In simply usage SPI is calculated by taking the difference of the precipitation, $\mathrm{Xi}$ from the mean, $\overline{\mathrm{X}}$ for a particular time step, and then dividing it by the standard deviation, $\sigma$ (Sonmez et al. 2005).

$$
\mathrm{SPI}=\frac{\mathrm{Xi}-\overline{\mathrm{X}}}{\sigma}
$$

However it is not so easy. Here long-term precipitation record is fitted to a probability distribution, commonly gamma distribution which is then transformed into a normal distribution so that the mean SPI for the location and desired period is zero (Edwards and McKee 1997).

$$
\mathrm{SPI}=\frac{\mathrm{a}-\mathrm{b}}{\mathrm{c}}
$$

Where, a - individual Gamma cumulative distribution value, $\mathrm{b}$ - mean, $\mathrm{c}$ - standard deviation.

SPI allows for monitoring both dry and wet conditions (Morid et al. 2006). Negative values indicate dry and positive values indicate wet periods (Damberg and AghaKouchak 2014). As the SPI becomes more negative or positive, the conditions become more severely dry or wet (Table 1). Details of the computation have been described extensively in McKee et al. (1993, 1995) and WMO (2012).
Table 1 Precipitation excess (wet) or deficit (dry) severity class according to SPI values and corresponding D-scale

\begin{tabular}{lll}
\hline SPI values & Draught severity class & D-Scale \\
\hline $2.0+$ & Extremely wet & W3 \\
1.5 to 1.99 & Very wet & W2 \\
1.0 to 1.49 & Moderately wet & W1 \\
-.99 to .99 & Near normal & $\mathrm{N}$ \\
-1.0 to -1.49 & Moderately dry & D1 \\
-1.5 to -1.99 & Severely dry & D2 \\
-2 and less & Extremely dry & D3 \\
\hline
\end{tabular}

Source: Based on the user guide of the WMO 2012

(URL: http://www.wamis.org/agm/pubs/SPI/WMO_1090_EN.pdf)

SPI was designed to quantify the precipitation deficit for multiple time scales (i.e. time interval). McKee et al. (1993) originally calculated the SPI for 3-, 6-, 12-, 24and 48-month time scales (also called 'time lag' or 'time step'). The 3-, 6-month SPI reflects short-term/seasonal condition (Ji and Peters 2003) and hence relevant for agricultural impact assessment; the 12-month SPI reflects medium-term annual water condition (Potop et al. 2012) and 24-months or more reflects long-term condition and relevant for assessment of socioeconomic impact (Potop et al. 2014). For the present case, typically SPI for 3-, 12-, 24- and 48-month's time steps are calculated. However, to explore the drought variation at inter-seasonal and inter-annual time scale more specifically the study will highlight $3-, 12$ - and 24-months step SPI.

\section{Drought risk evaluation parameters}

Drought intensity $\left(\mathbf{I}_{\mathbf{D}}\right) \mathbf{I}_{\mathrm{D}}$ annotates as the departure of a climate index from its normal value (Dupigny-Giroux 2001). According to McKee et al. (1993) a drought event is defined as a period in which the SPI is continuously negative and the SPI reaches a value of -1.0 or less. Hence, $I_{D}$ indicates the absolute value of SPI less than 1.0. Lesser the value more will be the drought intensity.

Drought severity $\left(S_{D}\right) S_{D}$ indicates some specific range of SPI (Table 1). As the SPI become more negative the conditions become more severely dry. For example, drought intensity ranges between -1.0 to $-1.49 ; 1.5$ to -1.99 and -2 and less are recognized as moderately dry; severely dry and extremely dry severity class respectively.

Drought duration $\left(D_{D}\right) \quad D_{D}$ equals the number of months between its start and end (Spinoni et al. 2014). A drought event starts when the SPI is continuously negative and reaches to an intensity of -1.0 or less while, the event ends when the SPI becomes positive. 
Drought magnitude $\left(M_{D}\right)$ and mean intensity $\left(M_{D}\right)$ $\mathrm{M}_{\mathrm{D}}$ corresponds to the cumulative water deficit over a drought period (Thompson 1999) and the average of this cumulative water deficit over the drought period is $\mathrm{MI}_{\mathrm{D}}$. Thus, $M_{D}$ is the absolute value of the sum of all SPI values during a drought event (Eq. 2) and $\mathrm{MI}_{\mathrm{D}}$ of a drought event refers to magnitude divided by duration (Eq. 3). The formulas are-

$$
\begin{aligned}
\mathrm{M}_{\mathrm{D}} & =\sum_{i=1}^{\mathrm{m}} \mathrm{SPI}_{\mathrm{ij}} \\
\mathrm{MI}_{\mathrm{D}} & =\frac{\sum_{\mathrm{i}=1}^{\mathrm{m}} \mathrm{SPI}_{\mathrm{ij}}}{\mathrm{m}} \text { or, } \mathrm{MI}_{\mathrm{D}}=\frac{\mathrm{M}_{\mathrm{D}}}{\mathrm{m}}
\end{aligned}
$$

Where, SPIij - SPI values of a drought event at $j$ time scale; $\mathrm{m}$ - number of months.

Drought frequency $\left(F_{D}\right) \quad F_{D}$ is used to assess the drought liability during a study period (Wang et al. 2014). The number of droughts per 100 years was calculated as:

$$
F_{D j, 100}=\frac{N j}{j . n} \times 100(\%)
$$

Where, $\mathrm{F}_{\mathrm{Di}, 100}$ is the frequency of droughts for time scale $\mathrm{j}$ in 100 years; $\mathrm{Nj}$ is the number of months with droughts for time scale $j$ in the $n$-year set; $j$ is time scale (3-, 6-, 12-, 24-months); $n$ is the number of years in the data set.

Frequency of Drought Station (fj) and Drought Station proportion $(\mathbf{P j}) \mathrm{Fj}$ is the number of stations encountered drought of a particular category $\left(n_{\mathrm{j}}\right)$ and is calculated by-

$$
\mathrm{F}_{\mathrm{j}}=\mathrm{n}_{\mathrm{j}}
$$

$\mathrm{Pj}$ is the ratio of number of stations where droughts occur and total number of stations. It indicates the spatial extent of drought occurrences in a region ( $\mathrm{Li}$ et al. 2012) and is calculated by-

$$
\mathrm{P}_{\mathrm{j}}=\frac{\mathrm{n}_{\mathrm{j}}}{\mathrm{N}_{\mathrm{j}}} \times 100 \%
$$

Where, $j$ indicates a time scale (say 3 -month), $n_{j}$ is number stations fall under a specific drought category (say severe drought i.e. when the SPI $=-1.5$ to -1.99 ) in a particular time scale $j$ (say for 3-months), and $N_{j}$ is total number of stations involved for the calculations.

Trend analysis The rank-based nonparametric Mann-Kendall method (Mann 1945; Kendall 1975) is applied to the long term data in this study to detect statistically significant trends. Sen's nonparametric method
(Sen 1968) was used to estimate the trends of slope in the time series data.

Return period or recurrence interval, Tr Bonaccorso et al. (2003) expressed return period of drought as a function of the statistical characteristics of historical long records of precipitation and of a threshold parameter. In the present study the original concept of the return period (Haan 1977) is used, i.e. the average number of years between events occurred above a threshold magnitude of drought.

Rainfall threshold/critical rainfall, $\mathbf{T}_{\mathbf{R D}}$ Referring to Eq. 1a critical/threshold rainfall to initiate drought can be calculated. Simply calculate the mean, $\bar{X}$ and standard deviation, $\sigma$ for a particular time step (say, for 3 month Dec-Jan-Feb of 30 years of continuous rainfall series data) for a particular station and specify the desired SPI (say -1.0) for which critical rainfall is to be calculated and put the values into the Eq. 7.

$$
\mathrm{Xi}=\sigma \mathrm{SPI}+\overline{\mathrm{X}}
$$

SPI values below -1 indicate a drought occurrence (McKee et al. 1993). If the values drop below -1 the severity of drought increases (Table 1). So, in the present study, critical rainfall values have been calculated at " 1 " SPI.

\section{Drought risk assessment method}

At present, literature pertaining to drought has focused extensively on its impact, awarding limited attention to risk assessment as a tool. But, effective drought management should be based on risk assessment as a primary means in mitigating the impact of drought (Wu et al. 2015; Eze 2018). Decision makers need to be better informed about the existing pattern of risk so that they can decide on the allocation of resources (Fontaine et al. 2009). Therefore, in the present article, a comprehensive Composite Drought Risk Index (CDRI) has been forwarded to assess the overall situation.

Evaluation of drought risk, integrating parameters of socio-economic, psychological, infrastructural etc. are some common practices. However, integration of large number of parameters without logical consideration produces biased result in many occasions. Therefore, in the present case only the physical variables related to drought as indicated in the previous subsection have been integrated to develop CDRI (Eq. 8) with the aim to assess the overall scale of the problem. Composite ranking (Foster et al. 2013; ARCC 2014) method has been used to derive the drought risk scores for each weather station. 
Table 2 List of selected parameters and their modes of ranking of the parameters for CDRI

\begin{tabular}{|c|c|c|c|c|}
\hline $\begin{array}{l}\text { SI } \\
\text { no. }\end{array}$ & Parameters & Sensitivity/logical consideration & $\begin{array}{l}\text { Relation to } \\
\text { drought }\end{array}$ & Mode of ranking \\
\hline 1 & Average rainfall & More the rainfall less the risk & Indirect & highest rank (i.e. 1) to lowest rainfall station \\
\hline 2 & Rainfall trend & $\begin{array}{l}\text { decreasing trend will indicate intensification } \\
\text { of dry condition and vice versa }\end{array}$ & Indirect & $\begin{array}{l}\text { highest rank (i.e. 1) to lowest trend value arranged } \\
\text { from lowest (extreme -ve) to highest (extreme +ve) }\end{array}$ \\
\hline 3 & Mean drought intensity & More the intensity ( $\mathrm{SPI} \leq 1.0$ ) more the risk & Direct & $\begin{array}{l}\text { highest rank (i.e. 1) to highest drought intensity } \\
\text { (extreme -ve SPI) }\end{array}$ \\
\hline 4 & Average drought duration & More duration means more risk & Direct & highest rank (i.e. 1) to highest drought duration \\
\hline 5 & Severe drought frequency (\%) & More frequency means more risk & Direct & highest rank (i.e. 1) to highest drought frequency \\
\hline 6 & Extreme drought frequency (\%) & More frequency means more risk & Direct & highest rank (i.e. 1) to highest drought frequency \\
\hline 7 & Trend of drought intensity & $\begin{array}{l}\text { +ve trend will indicate intensification of wet } \\
\text { condition and negative trend will indicate } \\
\text { intensification of dry condition. }\end{array}$ & Indirect & $\begin{array}{l}\text { highest rank (i.e. 1) to lowest trend (i.e. z) value } \\
\text { arranged from lowest (extreme }- \text { ve) to highest } \\
\text { (extreme +ve) }\end{array}$ \\
\hline 8 & $\begin{array}{l}\text { Recurrence interval of severe } \\
\text { drought }\end{array}$ & More the recurrence interval less the risk & Indirect & highest rank (i.e. 1) to lowest return period \\
\hline 9 & $\begin{array}{l}\text { Recurrence interval of extreme } \\
\text { drought }\end{array}$ & More the recurrence interval less the risk & Indirect & highest rank (i.e. 1) to lowest return period \\
\hline 10 & Threshold rainfall & $\begin{array}{l}\text { More the rainfall requirement more the } \\
\text { chances of drought }\end{array}$ & Direct & $\begin{array}{l}\text { Highest rank (i.e. 1) to highest critical rainfall } \\
\text { amount. }\end{array}$ \\
\hline
\end{tabular}

$$
\text { Composite Drought Risk Index }(C D R I)=\sum_{i=1}^{n} R i j
$$

Where, Rij means rank of $\mathrm{i}^{\text {th }}$ parameter at $\mathrm{j}^{\text {th }}$ location.

The directionality of influence and the mode of ranking of the parameters are given in Table 2.

Once drought risk scores are calculated using the aggregation tools discussed above, maps are prepared subsequently to show the spatial distribution of the overall risk scores.

\section{Data processing and related calculations and mapping}

The complete set of raw data for the said period (Jan 1901 to Dec 2002) in the current study have been tested to check if there are any missing data or irregularities in the data series. Then those data are re-arranged as per requirements. SPI is then calculated for several time frames (i.e. 3-, 12-, 24-months etc.) using the standard computerized programme, 'SPI Calculator' of the National Drought Mitigation Centre (NDMC) as recommended by WMO (2012). Once the SPI is determined, drought-related indicators (vide Drought risk evaluation parameters part) are then calculated. Statistical Package for Social Scientist (SPSS, 14.0) and XLSTAT 2015 Excel plug-in are used for the MK test and Sen's slope estimate. The subsequent spatial plots are provided in the gridded format for the rationale of revealing the general pattern over the region. For this purpose Surfer program (Version 10), that utilizes widely accepted Kriging interpolation technique to produce visually appealing contour and surface plots from irregularly spaced data has been used.

\section{Results and discussion}

\section{Assessment of the drought intensity}

Time series assessment of draught intensity at different time steps for the GWB

SPI time series calculated for the GWB between 1901 and 2002 for 3-, 12-, 24- and 48-month time steps are shown in Fig. 3. Noticeably, drought's characteristics change with time lag. At the longer time scales, droughts become less frequent but their duration increases (Fig. 3a to d).

On the 3-month time step (Fig. 3a), drought in February to April 1999 with $\mathrm{PI}_{\mathrm{D}}$ of -3.72 and $\mathrm{MI}_{\mathrm{D}}$ of 2.68 is the most significant. 12-month SPI series (Fig. 3b) ten significant droughts have occurred in between 1901 and 2002. Among them, drought of the year 1966-67 is the most significant with $D_{D}$ of 14 months; $\mathrm{PI}_{\mathrm{D}}$ of -2.82 and $\mathrm{MI}_{\mathrm{D}}$ of -2.06 . On 24-month time lag (Fig. 3c) six major droughts are identified during 1901-2002. Among them, the droughts of 19661968 is the most significant which lasted for 24 months, had a $\mathrm{PI}_{\mathrm{D}}$ of -2.62 and $\mathrm{a} \mathrm{MI}_{\mathrm{D}}$ of -2.14 .

Based on the 48 month SPI (Fig. 3d) the last century can be (roughly) categorized into some consecutive surplus and deficit phases: (i) Slight deficit phase-(1901 to 1917), (ii) Short surplus phase-(1918 to 1922); (iii) Oscillating or near normal phase-(1923 to 1940); (iv) Short surplus phase-(1941 to 1953); (v) longest and peak deficit phase-(1954 to 1970); (vi) 1st Peak surplus phase-(1971-82); (vii) Short deficit phase-(1983-86) and (viii) Longest surplus phase-(1987-2001). Notably, after 1950s the extremities of surplus and deficit as well as the duration have increased substantially. Table 3 clearly shows 

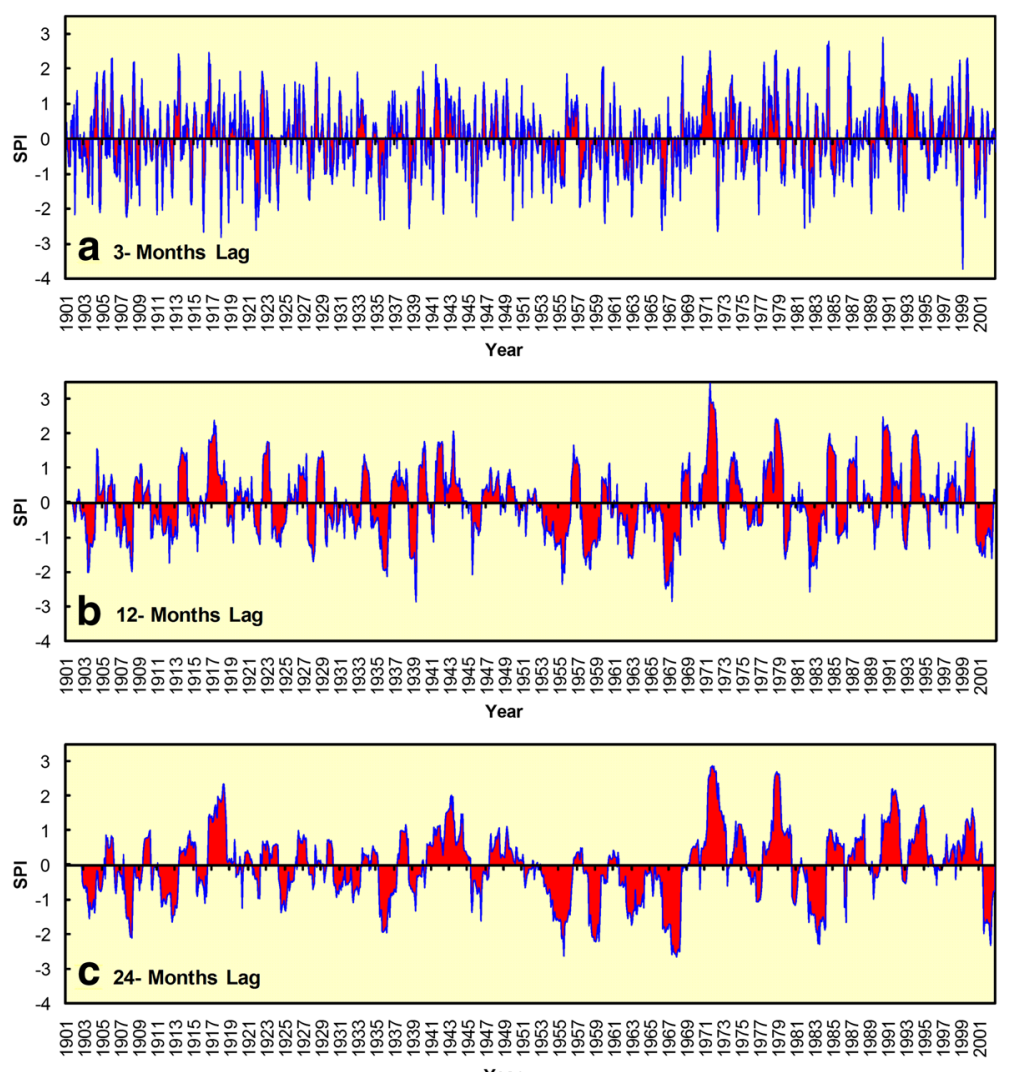

Year

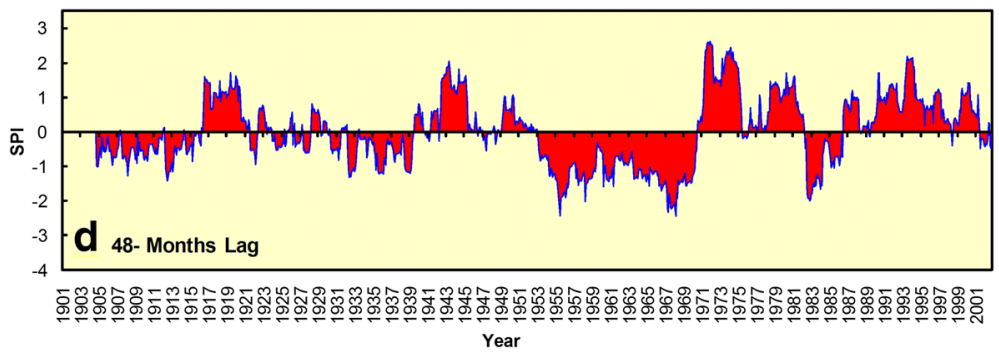

Fig. 3 SPI time series for GWB between 1901-2002 for (a) 3-, (b) 12-, (c) 24- and (d) 48- months time scales. Note: -ve SPI value indicates dry condition and +ve SPI value indicates wet condition, If SPI become more -ve or +ve, the conditions become more severely dry or wet

Table 3 Drought intensity at different time scale for GWB during 1901-2002

\begin{tabular}{|c|c|c|c|c|}
\hline \multirow[t]{2}{*}{ Lag time } & \multicolumn{3}{|c|}{$\begin{array}{l}\text { Observed Peak Intensity }\left(\mathrm{Pl}_{\mathrm{D}}\right) \\
\text { During 1901-2002 }\end{array}$} & \multirow[t]{2}{*}{ Mean Intensity $\left(\mathrm{MI}_{\mathrm{D}}\right)$} \\
\hline & SPI (D Scale) & Year & Month & \\
\hline 3-month & $-3.72(\mathrm{D} 3)$ & 1999 & April & -2.68 (gross avg. -0.81 ) \\
\hline 12-month & $-2.83(\mathrm{D} 3)$ & 1939 & June & -1.68 (gross avg. -0.77 ) \\
\hline 24-month & $-2.62(\mathrm{D} 3)$ & 1968 & January & -2.13 (gross avg. -0.81 ) \\
\hline 48-month & $-2.43(\mathrm{D} 3)$ & 1968 & May & -1.49 (gross avg. -0.79 ) \\
\hline
\end{tabular}

that, most of the drought event reaches to its maximum intensity during the pre-monsoon months March to May.

\section{Spatial character of the drought intensity}

During the 102 year time span the $\mathrm{MI}_{\mathrm{D}}$ at 3-, 12- and 24-month time step was $-0.81,-0.77$ and -0.81 respectively. $\mathrm{MI}_{\mathrm{D}}$ for most stations $(69.44 \%)$ at all the time scale were $\geq-0.8$ but did not cross the limit of mild drought (i.e. 0 to -0.99 ). Regional $\mathrm{MI}_{\mathrm{D}}$ varies between 0.75 (Krishnanagar) and - 0.86 (Purulia). Spatially (Fig. 4a to c), average drought intensity is the greatest in the degraded plateau region and western fringe of the Rarh region; it is less in the mature \& active delta region and eastern fringe of the Rarh plain. 


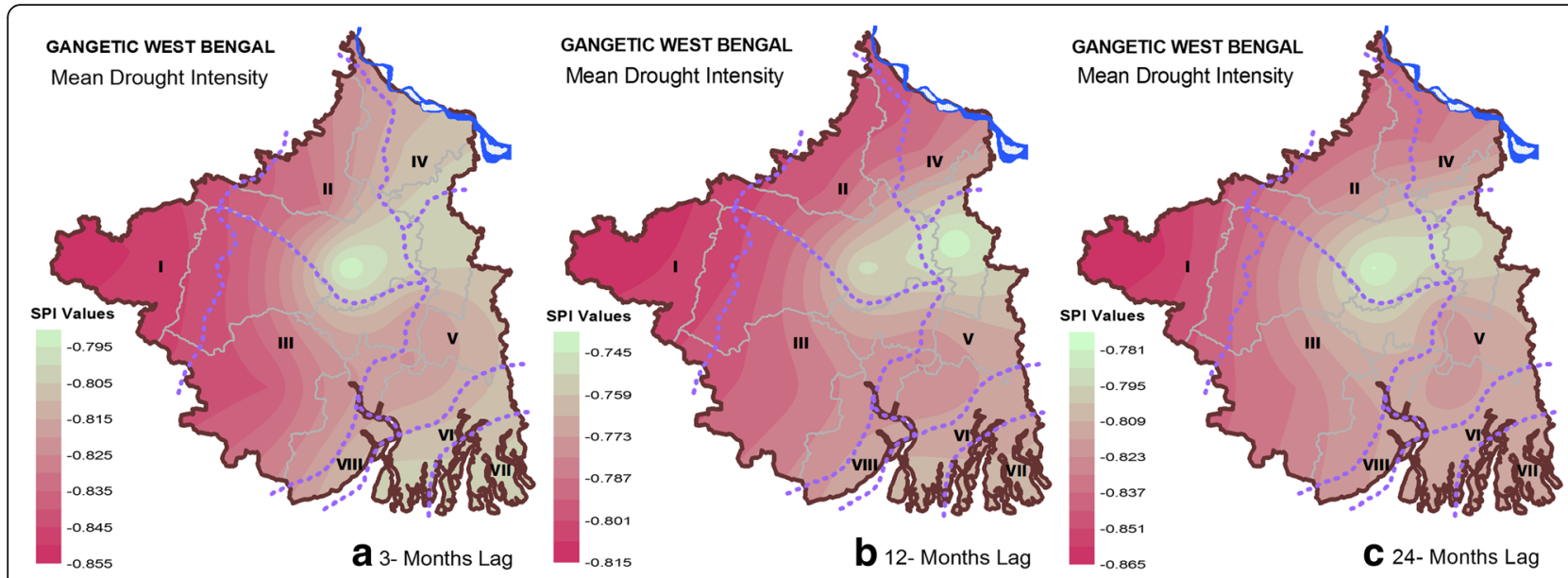

Fig. 4 Iso-average drought intensity map for (a) 3-, (b) 12-, (c) 24- months time scale

On spatial scale (Fig. 5a to c) at the 3-month step, observed $\mathrm{PI}_{\mathrm{D}}$ was highest in the mature delta region. At the 12-month scale $\mathrm{PI}_{\mathrm{D}}$ was greatest in the western degraded plateau region and the extreme northern part of moribund delta and Rarh plain region. At the 24 month scale $\mathrm{PI}_{\mathrm{D}}$ was highest in the western plateau and highlands. Thus the western degraded plateau region is more sensitive to long duration droughts.

\section{Spatial character of few historical droughts of 12-month duration}

On 12 months lag 1938-39, 1966-67, 1981-82 and 2001-02 are identified as the major severe draught year on the entire regional scale. Among these 1938-39 and 1966-67 were the most intense with the $\mathrm{PI}_{\mathrm{D}}$ of -2.83 and -2.82 respectively. During the 1966-67, SPI remained above -1.8 for about 14 months. The spatial character however varied widely. During 1938-39 Burdwan and Bankura of the central Rarh Bengal was affected intensively (Fig. 6a); it was Purulia of the degraded plateau region that affected much during 1967-68 and 2001-02 droughts (Fig. 6b and d). During 1981-82 drought (Fig. 6c) Berhampore (-3.08) and Sriniketan $(-2.0)$ of the Moribund delta and the northern Rarh Bengal respectively have affected intensely. In almost all of those sample years about $34 \%$ area of the GWB has experienced extremely dry condition.

\section{Duration and magnitude of drought events}

During 1901-2001, average drought duration on 12-, 24-month scale for most of the stations (>90.0\%) varied from 4 to 5 months and 5 to 7 months respectively and the $\mathrm{D}_{\mathrm{D}} \mathrm{A}(\mathrm{M})$ on 12-month time lag is 4.18 (Tables 4 \& 5). At the annual scale, $\mathrm{D}_{\mathrm{D}} \mathrm{L}(\mathrm{M})$ was more than 20 months and $\mathrm{D}_{\mathrm{D}} \mathrm{I}(\mathrm{M})$ was 7 month (Tables 4 \& 5). On annual scale $\mathrm{MI}_{\mathrm{D}}$ of the longest drought and the most intense drought event was 1.37 and -2.29 respectively. As per McKee et al. (1993) drought frequency decreases inversely and duration increases linearly with time scale. Here at the

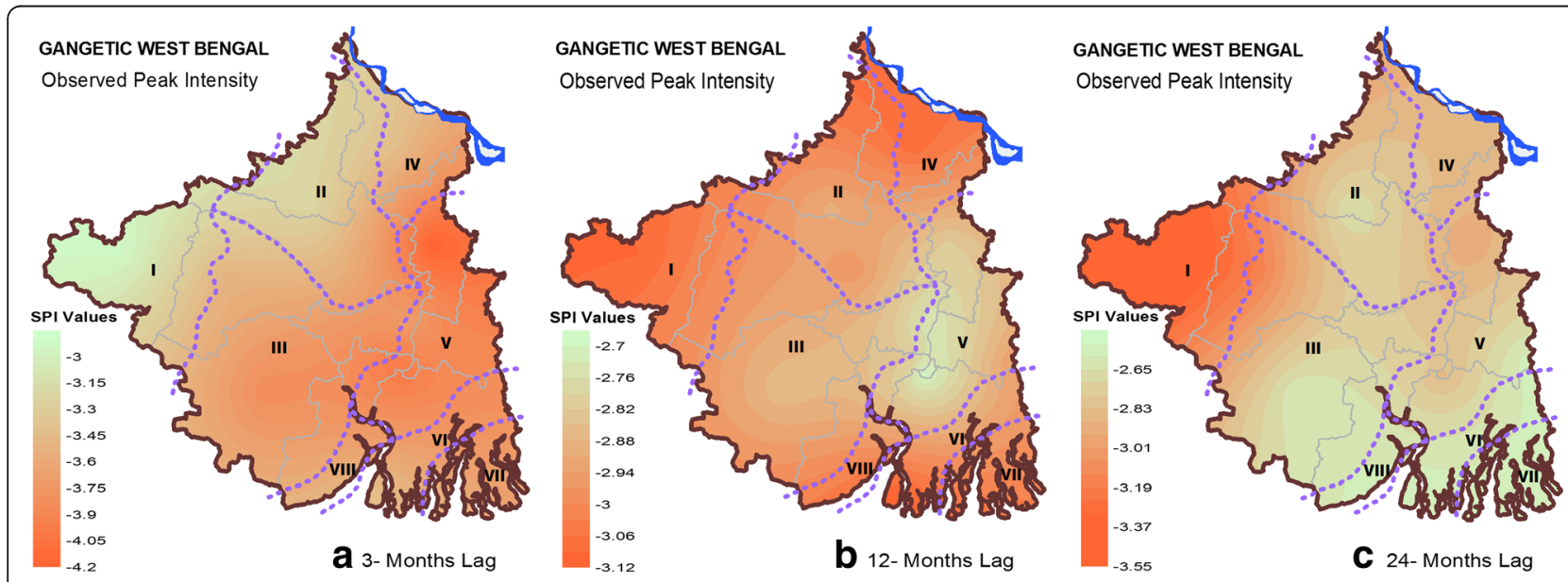

Fig. 5 Observed maximum intensity drought map at (a) 3-months (b) 12-months (c) 24-months time scale 


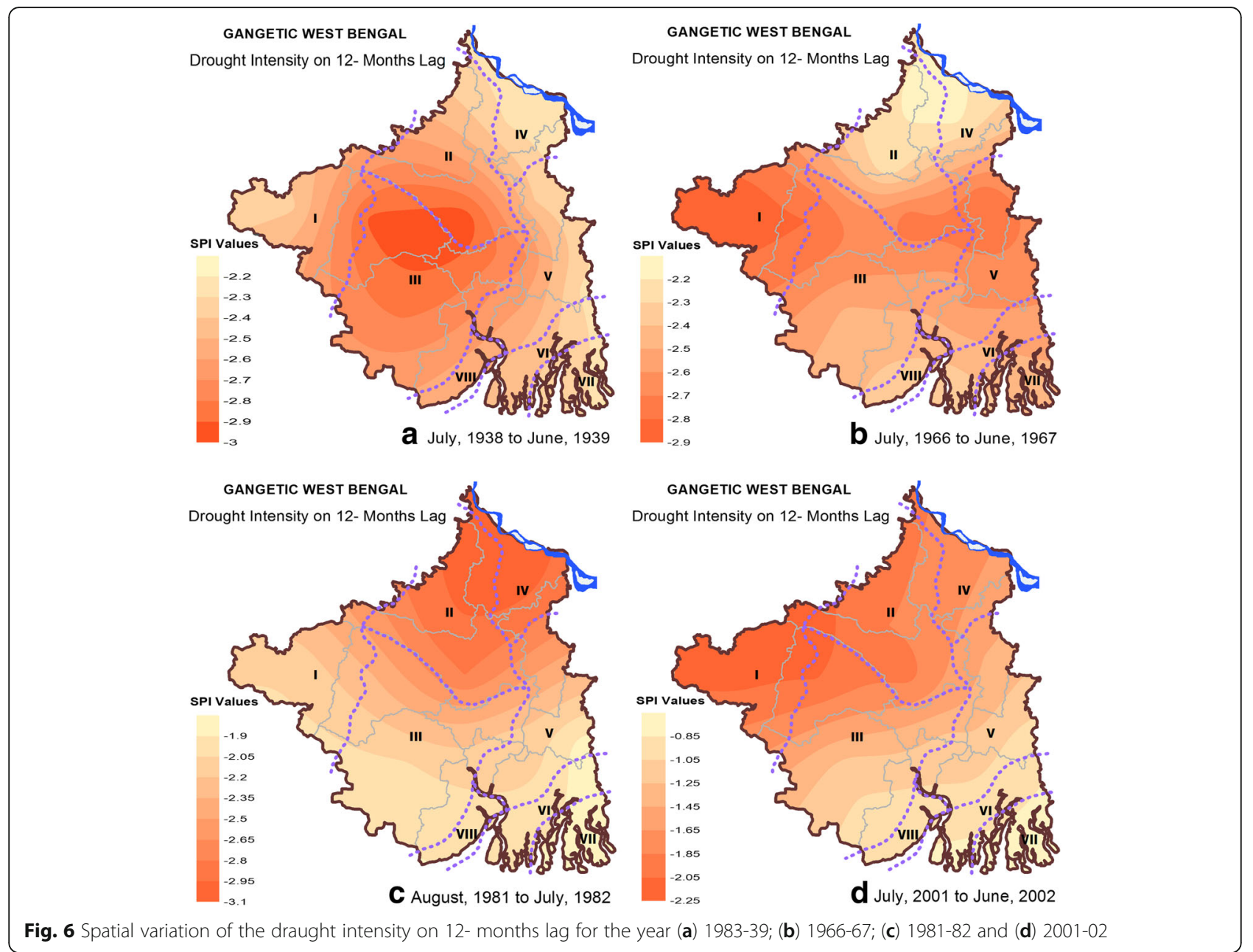

longer time scales, droughts become less frequent but their duration increases (Table 4).

Spatially at the shorter time span (3-month lag) the coastal plain followed by the southern Rarh and parts of the lower Ganga plain are sensitive to relatively longer drought duration (Fig. 7a). At the 12-month lag, it was relatively longer in the degraded plateau and plateau fringe fans of the Rarh Bengal duration (Fig. 7b). Noticeably the area suffered from lengthier drought duration (24-month SPI) counts low and western degraded plateau is most sensitive to the longer droughts duration (Fig. 7c).

Spatial character of the duration of longest and most intense drought at 12-months time lag and associated magnitude have been shown in Figs. 8 and 9 where duration of the longest and the most intense drought was relatively more in the western degraded plateau, moribund delta and plateau fringe fans region. While it was relatively lesser in the reclaimed middle, non-reclaimed lower Ganga plain and coastal plain region (Fig. 8). Noticeably the area suffered from lengthier drought, the drought magnitude was also counted more there (Fig. 9).

\section{Frequency of drought occurrences}

Percentage frequencies of drought occurrences of varying drought categories at different time steps have been

Table 4 Drought duration and magnitude distinctiveness at different time scale for the GWB during 1901-2002

\begin{tabular}{|c|c|c|c|c|c|c|c|c|c|}
\hline \multirow[t]{2}{*}{ Lag time } & \multicolumn{4}{|c|}{ Longest duration ( $\leq-1.0$ for consecutive months) } & \multicolumn{5}{|c|}{ Duration of most intense drought ( $\leq-2.0$ for consecutive months) } \\
\hline & $D_{D} L(M)$ & Year & $M_{D}$ & $\mathrm{MI}_{\mathrm{D}}$ & $\overline{D_{D}} \mid(M)$ & Year & $M_{D}$ & $\mathrm{Ml}_{\mathrm{D}}$ & $D_{D} A(M)$ \\
\hline 3-month & 7 & Nov, 1921 to May, 1922 & -12.75 & -1.82 & 3 & May, 1972 to July, 1972 & -7.31 & -2.44 & 1.96 \\
\hline 12-month & 21 & Sept, 1957 to May, 1959 & -28.76 & -1.37 & 7 & Sept, 1966 to March, 1967 & -16.05 & -2.29 & 4.18 \\
\hline 24-month & 27 & April, 1954 to June, 1956 & -42.12 & -1.56 & 13 & June, 1967 to June, 1968 & -31.45 & -2.42 & 7.56 \\
\hline
\end{tabular}

$D_{D} \mathrm{~A}(M)$ Avg. Duration (Month), $D_{D} L(M)$ Observed Longest Duration (Month), $D_{D} l(M)$ Observed Most Intense Duration (Month), $M_{D}$ Magnitude, $M I_{D}$ Mean Intensity 
Table 5 Drought duration and magnitude at 12-month time scale for different weather stations of the GWB

\begin{tabular}{|c|c|c|c|c|c|c|c|c|c|}
\hline \multirow{2}{*}{$\begin{array}{l}\text { Weather } \\
\text { station }\end{array}$} & \multicolumn{4}{|c|}{ Longest duration ( $\leq-1.0$ for consecutive months) } & \multicolumn{4}{|c|}{ Duration of most intense drought ( $\leq-2.0$ for consecutive months) } & \multirow[t]{2}{*}{$D_{D} A(M)$} \\
\hline & $D_{D} L(M)$ & Year & $M_{D}$ & $\mathrm{Ml}_{\mathrm{D}}$ & $D_{D} L(M)$ & Year & $M_{D}$ & $\mathrm{Ml}_{\mathrm{D}}$ & \\
\hline Berhampore & 24 & Sept, 2000 to Aug, 2002 & -32.18 & -1.34 & 11 & July, 1982 to May, 1983 & -27.87 & -2.53 & 4.57 \\
\hline Krishnanagar & 23 & July, 1966 to May, 1968 & -42.33 & -1.84 & 8 & Sept, 1982 to April, 1983 & -18.09 & -2.26 & 4.19 \\
\hline Chinsura & 21 & Sept, 1957 to May, 1959 & -28.13 & -1.34 & 7 & Oct, 1935 to April, 1936 & -15.53 & -2.22 & 3.93 \\
\hline Uluberia & 20 & Oct, 1957 to May, 1959 & 26.05 & 1.30 & 8 & Oct, 1935 to May, 1936 & -19.97 & -2.50 & 4.46 \\
\hline Alipore & 21 & Sept, 1957 to May, 1959 & -28.28 & -1.35 & 7 & Oct, 1935 to April, 1936 & -16.72 & -2.39 & 3.98 \\
\hline Basirhat & 23 & Sept, 1957 to July, 1959 & -37.63 & -1.64 & 8 & Oct, 1935 to May, 1936 & -21.02 & -2.63 & 4.55 \\
\hline Purulia & 25 & Aug, 2000 to Aug, 2002 & -46.23 & -1.85 & 12 & July, 1966 to June, 1967 & -33.34 & -2.78 & 5.17 \\
\hline Bankura & 23 & Sept, 2000 to July, 2002 & -36.58 & -1.59 & 12 & July, 1966 to June, 1967 & -31.59 & -2.63 & 5.08 \\
\hline Sriniketan & 23 & Sept, 2000 to July, 2002 & -34.06 & -1.48 & 7 & Aug, 1966 to Feb, 1967 & -16.15 & -2.31 & 5.15 \\
\hline Burdwan & 23 & Sept, 2000 to July, 2002 & -31.73 & -1.38 & 8 & Aug, 1966 to Mar, 1967 & -19.4 & -2.43 & 4.55 \\
\hline Midnpore & 20 & Sept, 1957 to April, 1959 & -25.75 & -1.29 & 8 & Sept, 1935 to April, 1936 & -20.55 & -2.57 & 5.07 \\
\hline Sagar Island & 20 & Oct, 1957 to May, 1959 & -24.52 & -1.23 & 9 & Sept, 1935 to May, 1936 & -29.43 & -3.27 & 4.17 \\
\hline GWB & 21 & Sept, 1957 to May, 1959 & -28.76 & -1.37 & 7 & Sept, 1966 to Mar, 1967 & -16.05 & -2.29 & 4.18 \\
\hline
\end{tabular}

$D_{D}(M)$ Duration (Month), $D_{D} L(M)$ Observed Longest Duration (Month), $D_{D} /(M)$ Observed Most Intense Duration (Month), $D_{D} A(M)$ Average Duration (Month), $M_{D}$ Magnitude, $M I_{D}$ Mean Intensity

outlined in Table 6 . At all the time steps, more or less $16 \%$ years (i.e. once in every 6 year) have recorded drought of all categories.

The regional character of the severe and extreme drought frequencies for 3-, 12-month and 2-year time steps have been portrayed in Figs. 10 \& 11. The interior parts especially the western degraded plateau and central Rarh plain are characterized with severe drought of lesser frequencies both at the shorter and at the longer-time steps (Fig. 10). Extreme drought occurrences, on the other hand, are more pronounced in the western degraded plateau region at both shorter and longer time steps (Fig. 11). The moribund delta and northern extreme of the Rarh plain are also prone to extreme drought at the 12 and 24-month scale (Fig. 11b and $\mathrm{c}$ ). This means that, the western degraded plateau and parts of the Rarh Bengal suffer from extreme drought condition frequently while parts of the Ganga delta suffer from recurrent severe drought conditions.

\section{Phase-wise pattern of drought intensity, duration and frequency}

To evaluate the Phase-wise change of drought variables during 1901-2002, the annual rainfall data series have been fitted with LOWESS or Locally Weighted Regression Curves (Cleveland 2012a, 2012b) to identify the patterns over time (Fig. 12) and thereby to divide the entire time span into some clearly distinct phases (Table 7).

From the Fig. 12 three clearly distinct Phase can roughly be identified-1901-1933; 1934-1964, 1965-

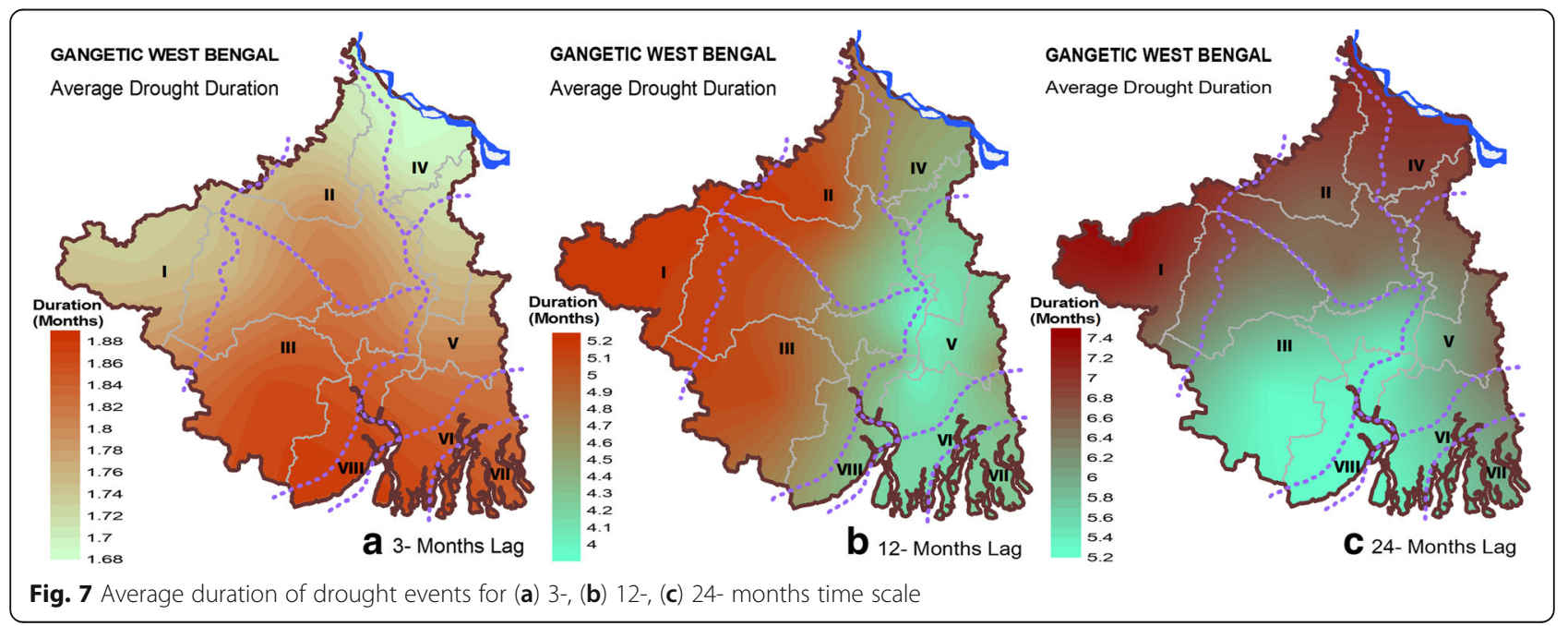



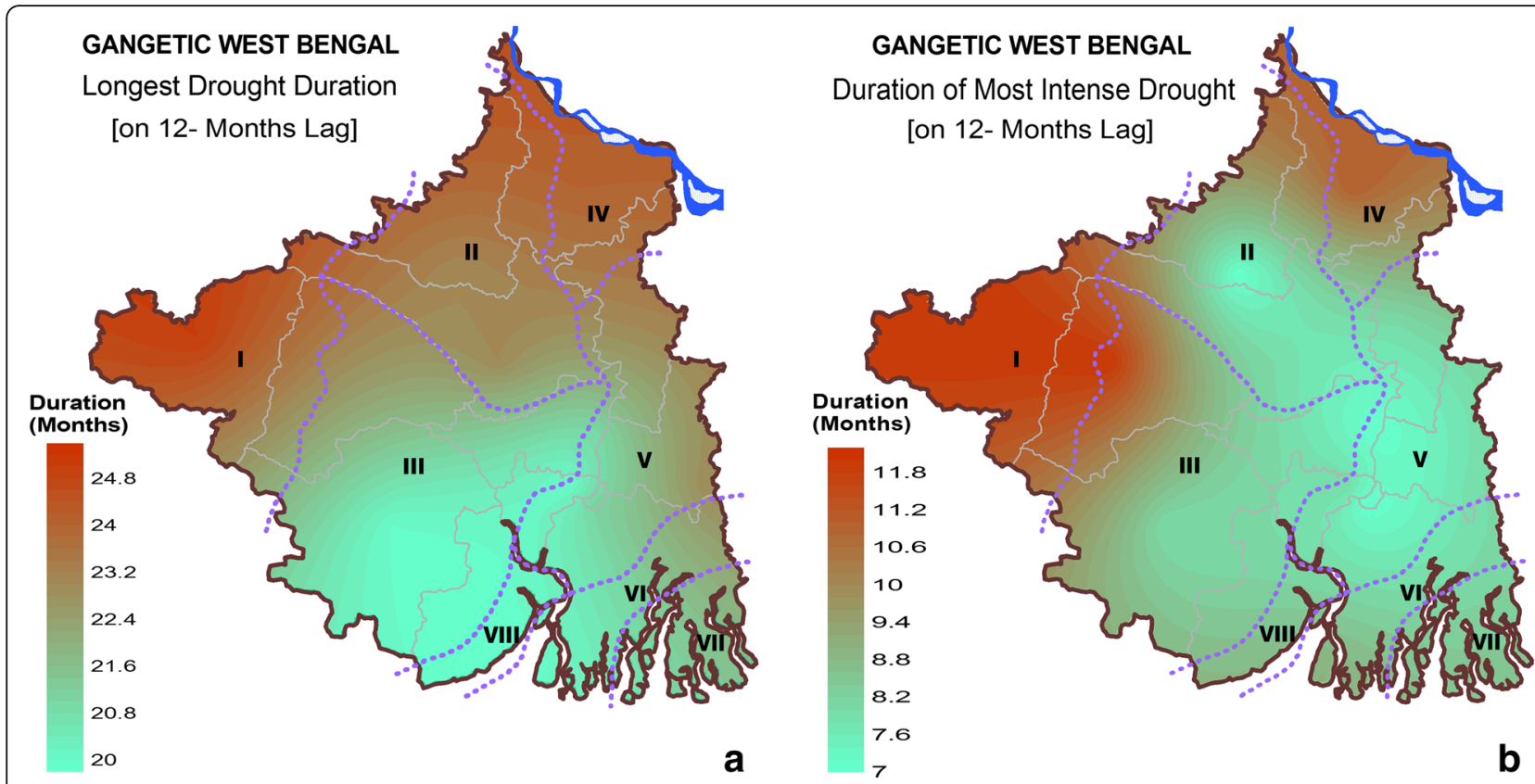

Fig. 8 (a) At 12-months time lag (a) longest duration and (b) duration of the most intense drought (SPI= $\mathrm{m}-2.0)$

2002. From Table 7 it is quite clear that, the average as well as peak intensity of drought has increased significantly during first two consecutive phases (from 0.71 to -0.82 and from -1.98 to -2.83 respectively). Meanwhile, there is no obvious change in average and maximum drought intensity between Phase-II and III. Actually, the drought intensity has stepped up in the latter half of the twentieth century. The average drought duration has increased from 2.6 months (Phase-I) to 5.5 month (Phase-II) and again has decreased to 4.4 months (Phase-III). Meanwhile, the regional average maximum drought duration has increased from 10 to 21 months in the Phase-II which has decreased to 14 months in the last phase while the most intense duration has increased from 8 month (Phase-I) to 11 month (Phase-II) and again equalized to 7

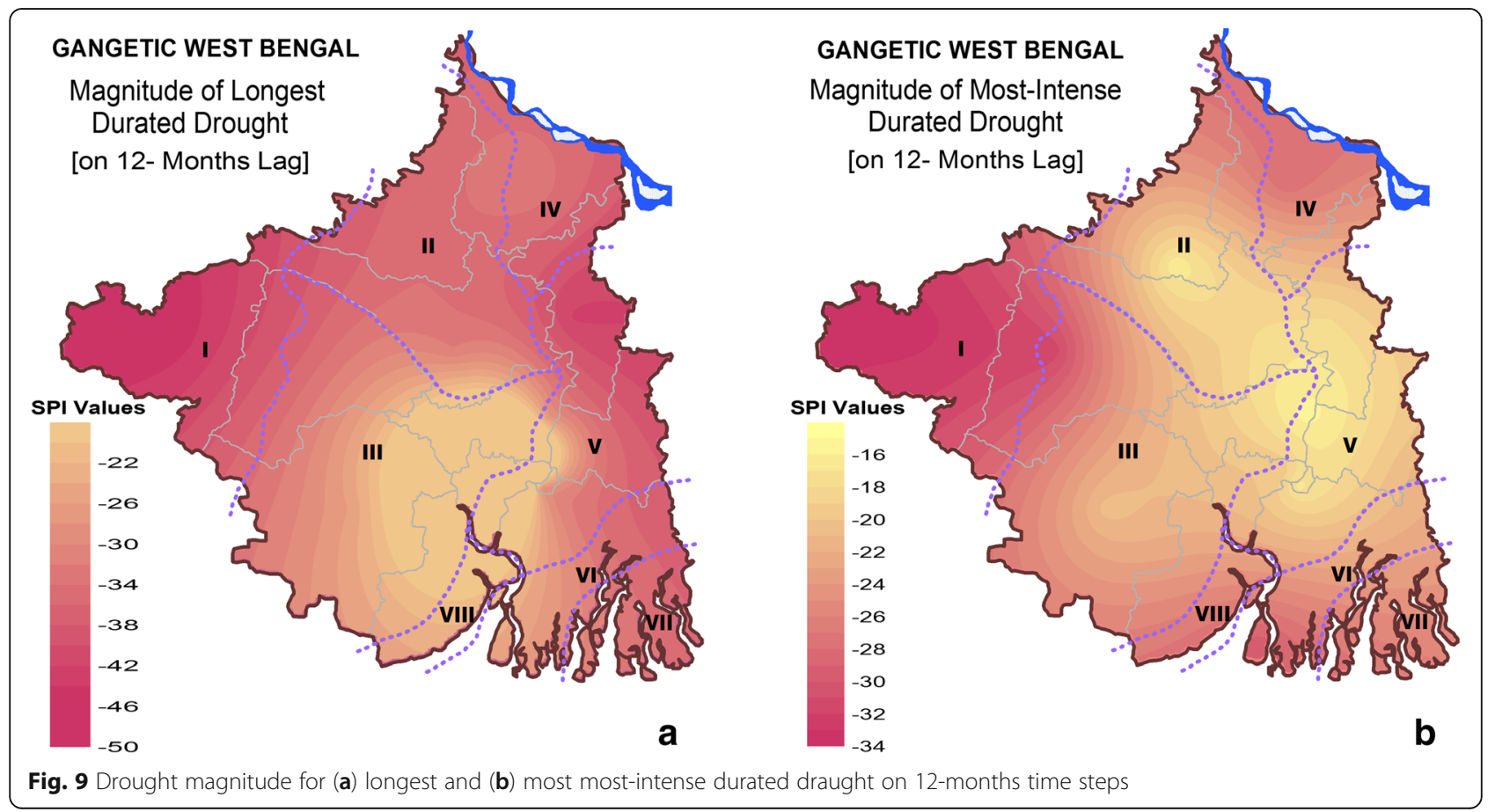


Table 6 Drought occurrences (\%) in GWB at corresponding drought categories and time steps

\begin{tabular}{llllll}
\hline Draught Severity Class & SPI values & 3-M. Lag & 12-M Lag & 24-M Lag & 48-M Lag \\
\hline Moderately dry (D1) & $(-1.0$ to -1.49$)$ & 8.76 & 10.80 & 7.83 & 13.08 \\
Severely dry (D2) & $(-1.5$ to -1.99$)$ & 4.09 & 4.20 & 5.66 & 3.91 \\
Extremely Dry (D3) & $(-2$ and less) & 3.11 & 1.24 & 16.66 & 1.10 \\
Total (\%) of all categories drought & & 15.96 & 16.24 & 16.15 & 18.10 \\
\hline
\end{tabular}

months (Phase-III). This may seem to be a good sign, but there is significant increase in mean intensity in the most intense durated drought from -1.46 in phase-I to as maximum as -2.06 in Phase-III. This signifies that extreme drought events become short durated but its intensity is escalating as a signature of climate change. Drought frequency particularly the moderate and the extreme have increased greatly during the consecutive phases. The regional extreme drought frequency during 1965-2002 compared to 1901-1933 has increased about 2\%. Stepping up of the Maximum drought intensity; mean intensity of the most intense drought event; average drought duration; severe and extreme drought frequency are some alarming threat to think over the existing strategies to cope with droughts in this agricultural tract.

\section{Drought trend assessment}

The MK test has been used to identify trends of drought intensity. It is important to note that, in case of rainfall, positive and negative trend indicate rainfall is increasing and declining respectively. Conversely, if rainfall decreases, there will be more chance to increase the drought intensity hence trend of drought intensity is inversely related to the rainfall trend. Therefore, in case of drought analysis, positive trend value will indicate intensification of wet condition and negative change will indicate amplification of dry condition. Table 8 shows the results and subsequently portrays on map (Fig. 13).

At all the time steps, stations Berhampore, Purulia, Bankura, Sriniketan and Burdwan, irrespective of their level of significance, have experienced amplification of dry condition over the assessed period. For the 3-month step, significant positive trends (on 95\% sig. level) have been detected at Berhampore and Sriniketan of the Moribund deltaic and northern Rarh region respectively. At the same time step significant positive trends (on $90 \%$ sig. level) have been detected in Purulia. For the station Sriniketan and Purulia the trend remains analogous for the 12- and 24-month time series also. However, on longer time span of 24-month scale, station Berhampore of the Moribund deltaic Bengal has experienced insignificant growth on $95 \%$ level of significance unlike the 3 - and 12-month scale.

\section{Drought returns periods}

The estimated return periods are portrayed in the Figs. 14 and 15. Fascinatingly, the return periods are increasing as the time scales are increasing and also with the increasing drought severity i.e. greater the severity and time scales, as expected, occur in higher return

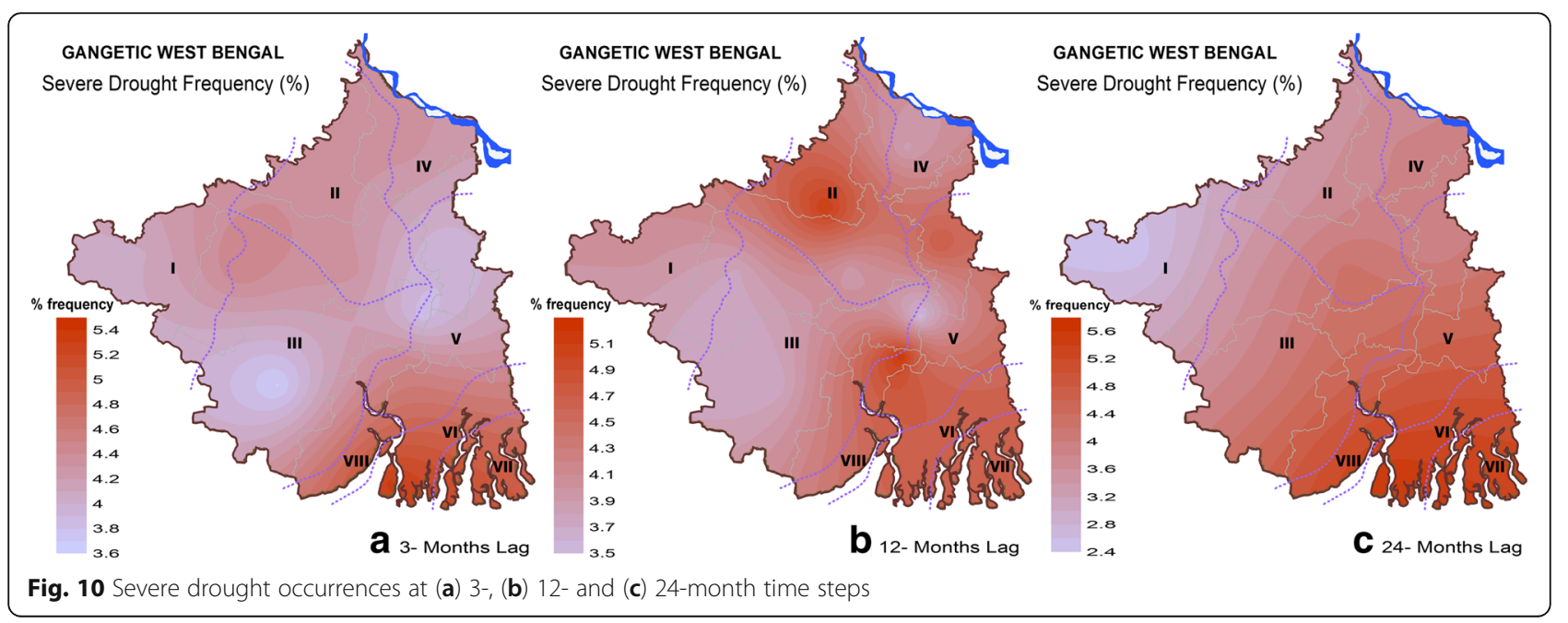




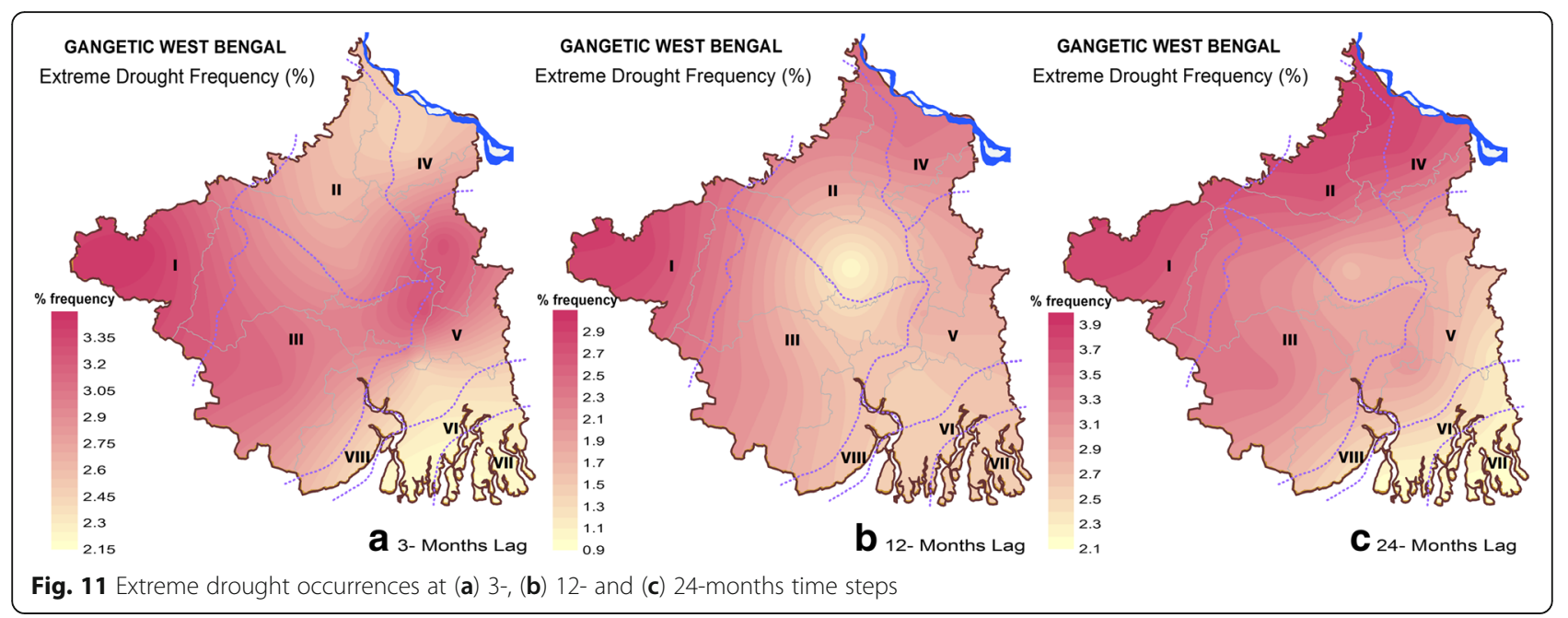

periods. In case of severe drought both at the shorter and longer time scale, the return periods are lesser in the South-eastern GWB (Fig. 14). However, the circumstances get reversed in case of the extreme drought (Fig. 15). In this case, the western degraded plateau and some parts of the plateau fringe fans especially the northern part, the return period count lesser. It indicates that, in these regions extreme drought strikes more frequently. Thus, on the entire regional scale, the southern deltaic Bengal and the coastal parts are more sensitive to frequent attack of severe drought; but extreme drought attack more recurrently in the western degraded plateau and in some parts of the Rarh Bengal.

\section{Critical (threshold) rainfall analysis}

Critical rainfall is the least amount of rainfall below which can initiate drought (Sonmez et al. 2005). At the 3-month time step, critical rainfall demands are more in the mature delta, southern Rarh and moribund delta region where large areas of irrigated cropland exists (Fig. 16a). At 12-month time step, areas of highest rainfall requirement moved to the south and concentrated in three pockets (Fig. 16b). At 24-month time step, critical rainfall values reach their maximum in the mature deltaic Bengal and southern part of the plateau fringe fans (Fig. 16c). Therefore, it is likely that the interior region immediately after the coastal and lower Ganga delta will be more exposed to droughts particularly the non-irrigated croplands.

\section{Drought risk assessment}

Drought is a stochastic natural hazard that arises from considerable deficiency in precipitation and subsequent impacts are realized on agriculture and hydrology. Droughts

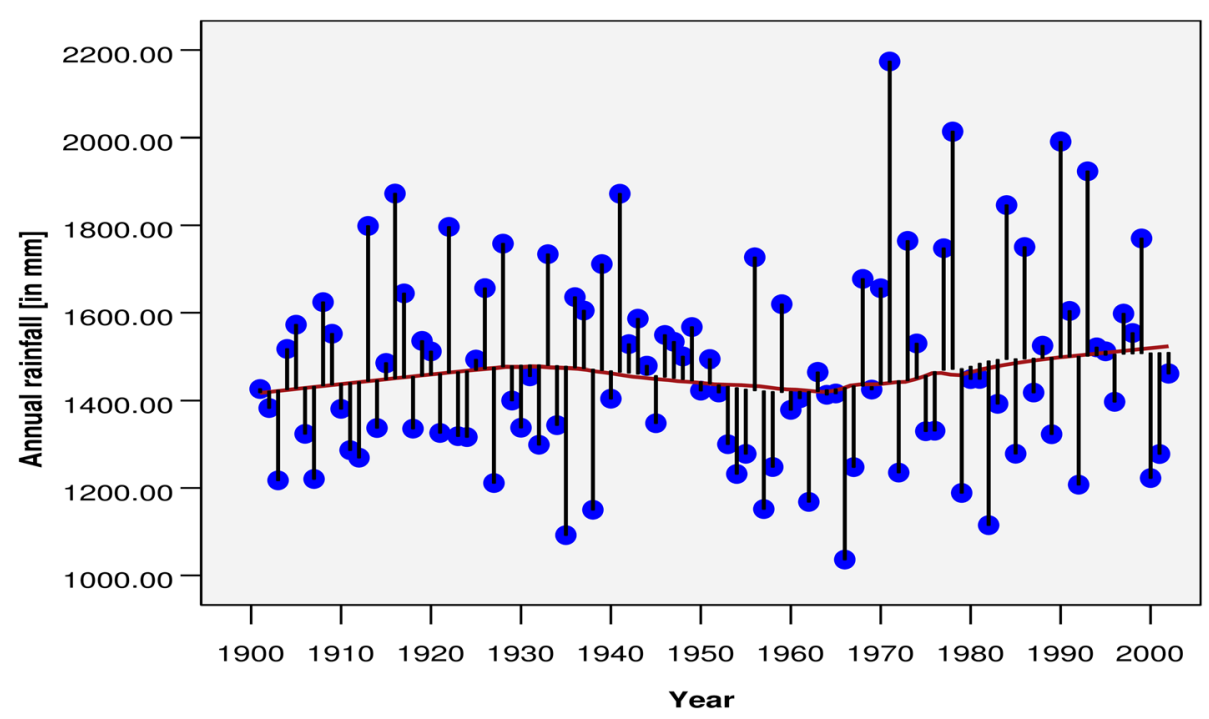

Fig. 12 Locally weighted regression (LOWESS) and scatter plots of the average annual rainfall in GWB for the period 1901-2002 
Table 7 Regional intensity, duration and frequency of drought events identified from SPI values at a 12-month scale for different periods in GWB

\begin{tabular}{|c|c|c|c|c|}
\hline Drought Indicators & Phase-l: 1901-1933 & Phase-II: 1934-1964 & Phase-III: 1965-2002 & 1901-2002 \\
\hline Average Drought Intensity $\left(\mathrm{MI}_{\mathrm{D}}\right)$ & -0.71 & -0.82 & -0.77 & -0.77 \\
\hline Maximum Drought Intensity $\left(\mathrm{Pl}_{D}\right)$ & $-1.98,1903$, July & $-2.83,1939$, June & $-2.82,1967$, June & $-2.83,1939$, June \\
\hline $\begin{array}{l}\text { Average Drought Duration }\left(D_{D} A(M)\right) \\
\text { (SPI: } \leq-1.0 \text { for consecutive months) }\end{array}$ & 2.61 & 5.54 & 4.39 & 4.18 month \\
\hline $\begin{array}{l}\left.\text { Maximum Drought Duration ( } D_{D} L(M)\right) \\
\text { (SPI: } \leq-1.0 \text { for consecutive months) }\end{array}$ & $\begin{array}{l}10 \text { month (August, } 1927 \\
\text { to May, 1928) }\end{array}$ & $\begin{array}{l}21 \text { month (Sept, } 1957 \\
\text { to May, 1959) }\end{array}$ & $\begin{array}{l}14 \text { month (July, } 1966 \\
\text { to August, 1967) }\end{array}$ & $\begin{array}{l}21 \text { month (Sept, } 1957 \\
\text { to May, 1959) }\end{array}$ \\
\hline $\begin{array}{l}\text { Most Intense Duration }\left(D_{D} \mid(M)\right) \\
\text { (SPI: } \leq-2.0 \text { for consecutive months) }\end{array}$ & $\begin{array}{l}8 \text { month (July, } 1903 \text { to } \\
\text { Feb, 1904). Mean } \\
\text { Intensity: }-1.46\end{array}$ & $\begin{array}{l}11 \text { month (Sept, } 1938 \\
\text { to July, 1939). Mean } \\
\text { Intensity: }-1.68\end{array}$ & $\begin{array}{l}7 \text { month (Sept, } 1966 \\
\text { to March, 1967). Mean } \\
\text { Intensity: -2.06 }\end{array}$ & $\begin{array}{l}7 \text { month (Sept, } 1966 \\
\text { o March, 1967): Mean } \\
\text { Intensity: - } 2.06\end{array}$ \\
\hline Moderate Drought Frequency (\%) & 10.65 & 10.65 & 12.73 & 10.80 \\
\hline Severe Drought Frequency (\%) & 2.69 & 6.72 & 4.30 & 4.20 \\
\hline Extreme Drought Frequency (\%) & 0 & 1.32 & 1.97 & 1.24 \\
\hline
\end{tabular}

vary by multiple dynamic dimensions including severity, duration, return period etc. Therefore, efficient drought management should enable both retrospective analyses (e.g., severity, duration etc. versus impact assessment) and prospective planning (e.g., risk assessment). Retrospective analyses have been done in the previous sub-sections. The present section will assess risk by assimilating indicators that are discussed earlier. The aim is not to manage it but to assess the overall condition, a fundamental step in mitigation preparedness.

On short-term or seasonal scale the northern Rarh is the most exposed to drought (Fig. 17a). On the annual scale as well as on long term scale the western degraded plateau is the most open to drought followed by northern Rarh
Bengal (Fig. 17b and c). The temporal reference also indicates that most of the parts of this region experienced the worst droughts in the last century. Apart from those two, both on short term and long term cases the moribund delta and the western fringe of the southern Rarh region are also exposed to drought hazard. In the last two decades, the maximum number of sequential arid years, agriculture of these two regions affected severely and the trend of drought condition in this area is increasing, confirming that drier condition is progressing towards these regions.

\section{Summary and conclusion}

The present study has provided results on the assessment of meteorological drought condition for the GWB

Table 8 Result of MK (MMK) test, Sen's slope and \% change over 1901-2002 in different drought series

\begin{tabular}{|c|c|c|c|c|c|c|c|c|c|}
\hline \multirow{2}{*}{$\begin{array}{l}\text { Weather } \\
\text { Stations }\end{array}$} & \multicolumn{3}{|l|}{ SPI-3 } & \multicolumn{3}{|l|}{ SPI-12 } & \multicolumn{3}{|l|}{ SPI-24 } \\
\hline & Z & Q & Trend & Z & Q & Trend & Z & Q & Trend \\
\hline Berhampore & $-1.30^{*}$ & -0.21 & $\ln { }^{*}$ & $-2.05^{*}$ & -0.49 & $\ln { }^{*}$ & $-1.87^{+}$ & -0.59 & $\ln ^{+}$ \\
\hline Krishnanagar & 0.44 & 0.07 & De & 0.94 & 0.22 & De & 1.49 & 0.39 & De \\
\hline Chinsura & 1.17 & 0.17 & De & 1.86 & 0.48 & De & $2.52^{+}$ & 0.75 & $\mathrm{De}^{+}$ \\
\hline Uluberia & $1.75^{+}$ & 0.24 & $\mathrm{De}^{+}$ & $2.77^{+}$ & 0.71 & $\mathrm{De}^{+}$ & $3.23^{*}$ & 0.99 & $D e^{*}$ \\
\hline Alipore & $1.46^{+}$ & 0.22 & $\mathrm{De}^{+}$ & $2.40^{+}$ & 0.61 & $\mathrm{De}^{+}$ & $2.98^{*}$ & 0.91 & $D e^{*}$ \\
\hline Basirhat & $1.98^{*}$ & 0.32 & $D e^{*}$ & $3.27^{*}$ & 0.81 & $D e^{*}$ & $3.88^{*}$ & 0.15 & $D e^{*}$ \\
\hline Purulia & -1.26 & -0.18 & $\ln ^{+}$ & $-1.79^{+}$ & -0.44 & $\ln ^{+}$ & $-1.95^{+}$ & -0.60 & $\ln ^{+}$ \\
\hline Bankura & -0.53 & -0.10 & $\ln$ & -0.80 & -0.18 & $\ln$ & -0.63 & -0.20 & $\ln$ \\
\hline Sriniketan & $-1.49^{*}$ & -0.24 & $\ln ^{*}$ & $-2.53^{*}$ & -0.63 & $\ln { }^{*}$ & $-2.77^{*}$ & -0.85 & $\ln { }^{*}$ \\
\hline Burdwan & -0.45 & -0.06 & $\ln$ & -0.81 & -0.18 & $\ln$ & -0.61 & -0.16 & $\ln$ \\
\hline Midnpore & 1.33 & 0.20 & De & 2.22 & 0.55 & De & $2.81^{+}$ & 0.80 & $\mathrm{De}^{+}$ \\
\hline Sagar Island & $2.17^{*}$ & 0.34 & $D e^{*}$ & $3.48^{*}$ & 0.89 & $\mathrm{De}^{*}$ & $4.00^{*}$ & 0.25 & $D e^{*}$ \\
\hline GWB Avg. & 0.53 & 0.08 & De & 0.92 & 0.24 & De & 1.56 & 0.44 & De \\
\hline
\end{tabular}

Z: Standardized test statistics of MK test; Q-Sen's slope estimate; In-increasing and De-Decreasing trend of dry condition. ${ }^{*}$ Represents significant trend at 0.05 level of significance; and ${ }^{+}$represents significant trend at 0.1 level of significance 


\section{GANGETIC WEST BENGAL}

Single Site Drought Trend

\section{$\underline{\text { Index }}$}

$\triangle$ Increasing trend

$\nabla$ Decreasing trend

$\triangle$ Significant increasing trend

$\nabla$ Significant decreasing trend

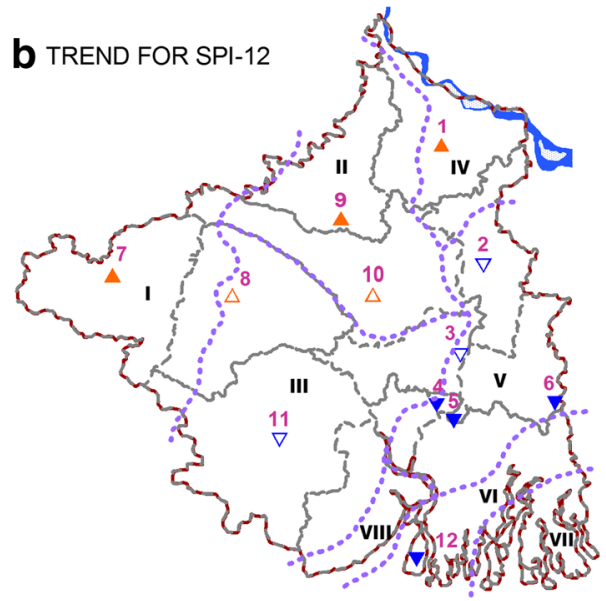

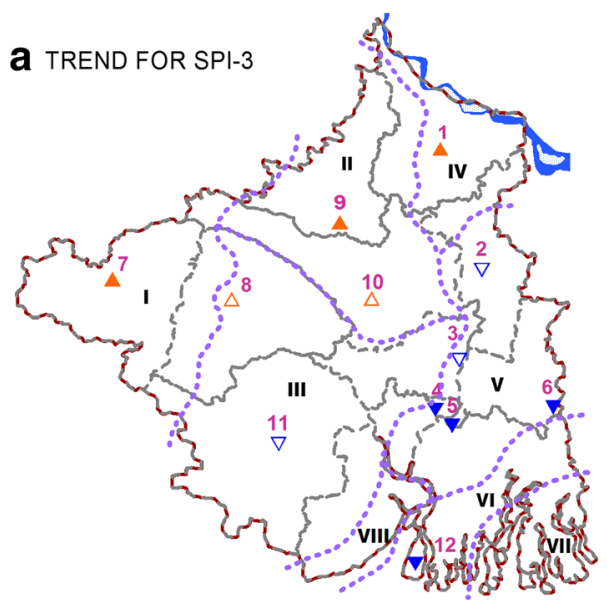

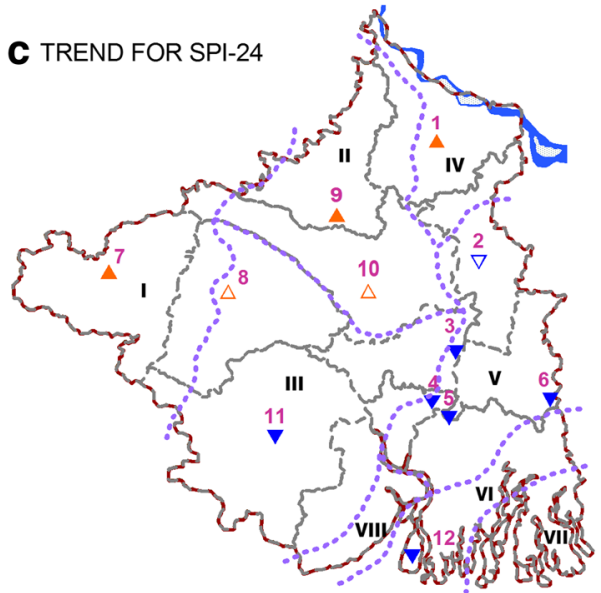

Fig. 13 Single-site trend of drought intensity (1901-2002) for SPI at (a) 3-, (b) 12- and (c) 24-months time scales

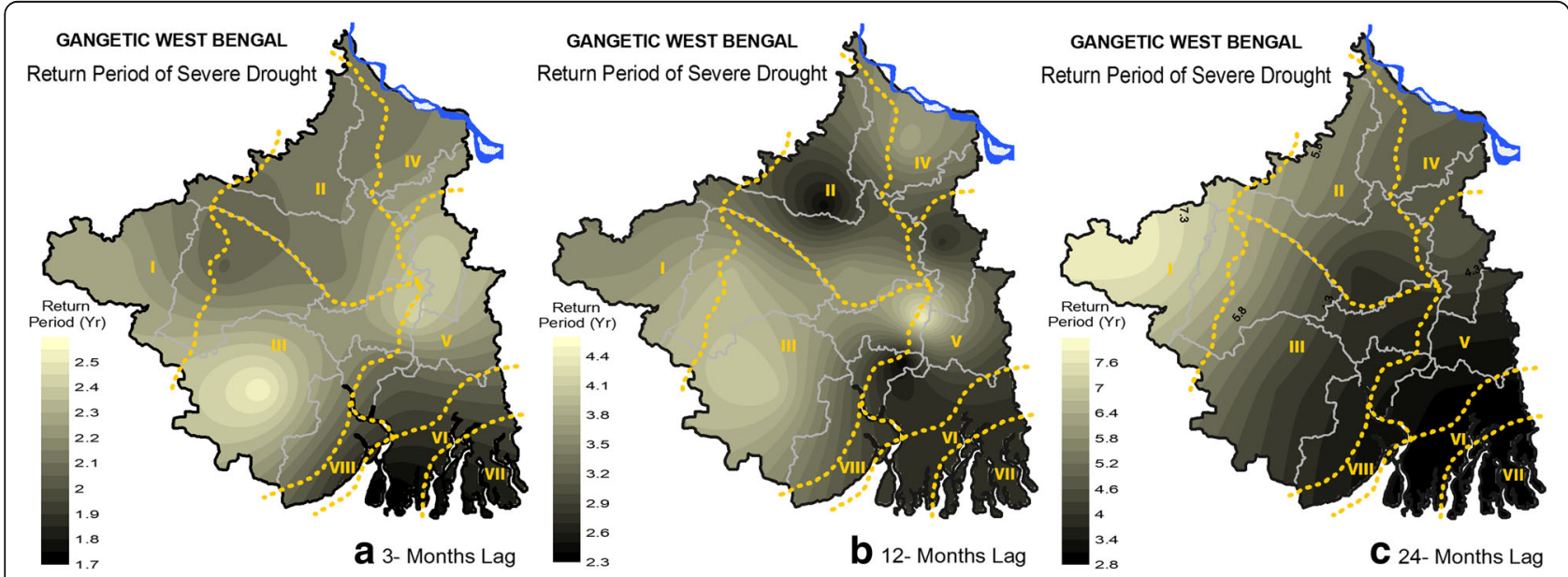

Fig. 14 Return period of severe drought (SPI <-1.5 to -1.99) on (a) 3- (b) 12- and (c) 24- months time steps 


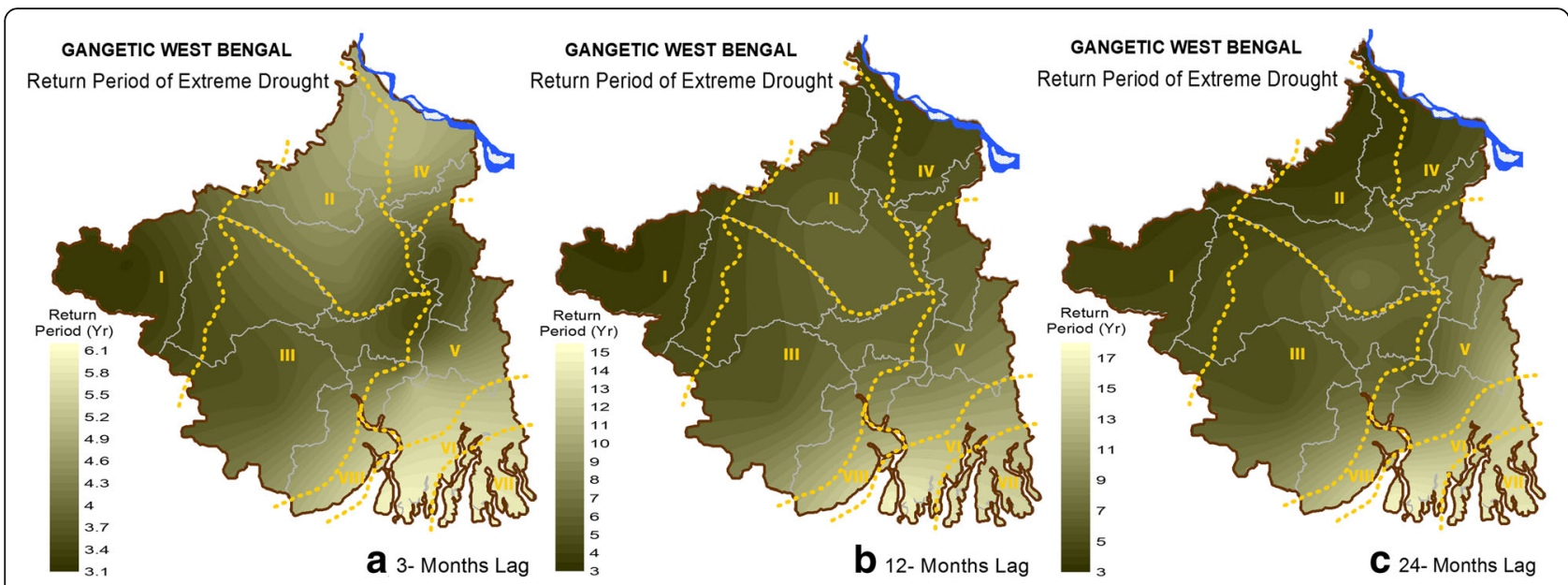

Fig. 15 Return period of extreme drought (SPI <-2.0) on (a) 3-month (b) 12-month and (c) 24 month time steps

over the last century in the context of climate change. The patterns of drought frequency, magnitude, duration, trend etc. are portrayed through statistical assessment, visually interpretive maps and geographic description. By employing widely accepted scientific methodology, the present assessment let judgment of the circumstances and supposed to improve our understanding of drought jeopardy in this region.

The study confirmed that, the last century exhibits some consecutive deficit and surplus phases and after 1950s extremity of surplus and deficit as well as duration have been increased substantially. Stepping up of the maximum drought intensity; mean intensity of the most intense drought event; average drought duration; severe and extreme drought frequency from 1940s in this agricultural tract are some alarming events to think over. At the spatial scale, the results also portray very diverse but consistent picture. The western degraded plateau is more sensitive to extreme droughts and average drought intensity as well as draught duration are greatest there. However, the impact of drought is expected to be rigorous at or adjacent areas of the western degraded plateau, particularly the northern Rarh and moribund delta where the drought intensities are tend to increase while the rainfall as well as recurrence interval of drought are tend to lessen. The western degraded plateau is widely known for its drought proneness (WBPCB 2009). But, the most important thing is that, this work provides evidences demonstrating the extension and intensification of dryness in the adjacent areas of this traditional drought prone region namely- towards the northern Rarh plain and Moribund delta.

The observations are harmonizing with few available studies on related grounds for the present study area. Study of Ghosh (2018) highlighted a considerable decrease of rainfall in early monsoonal month of June

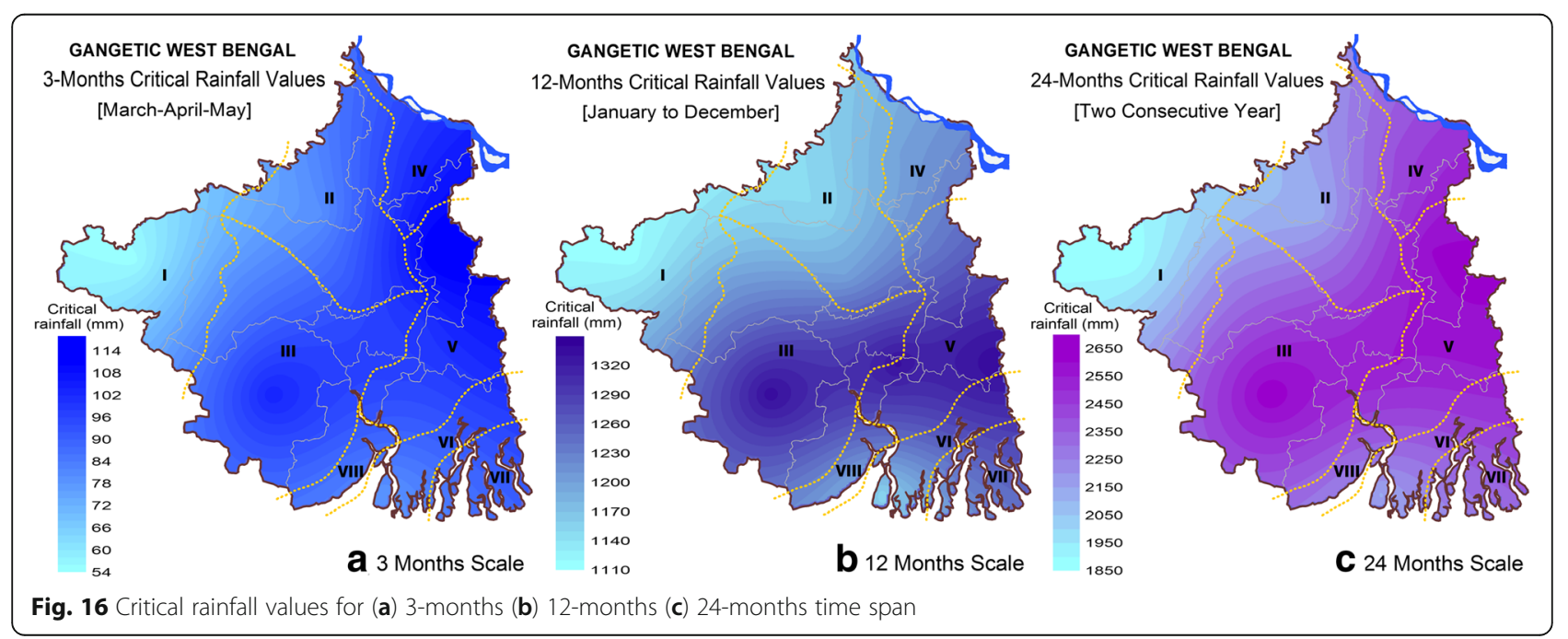




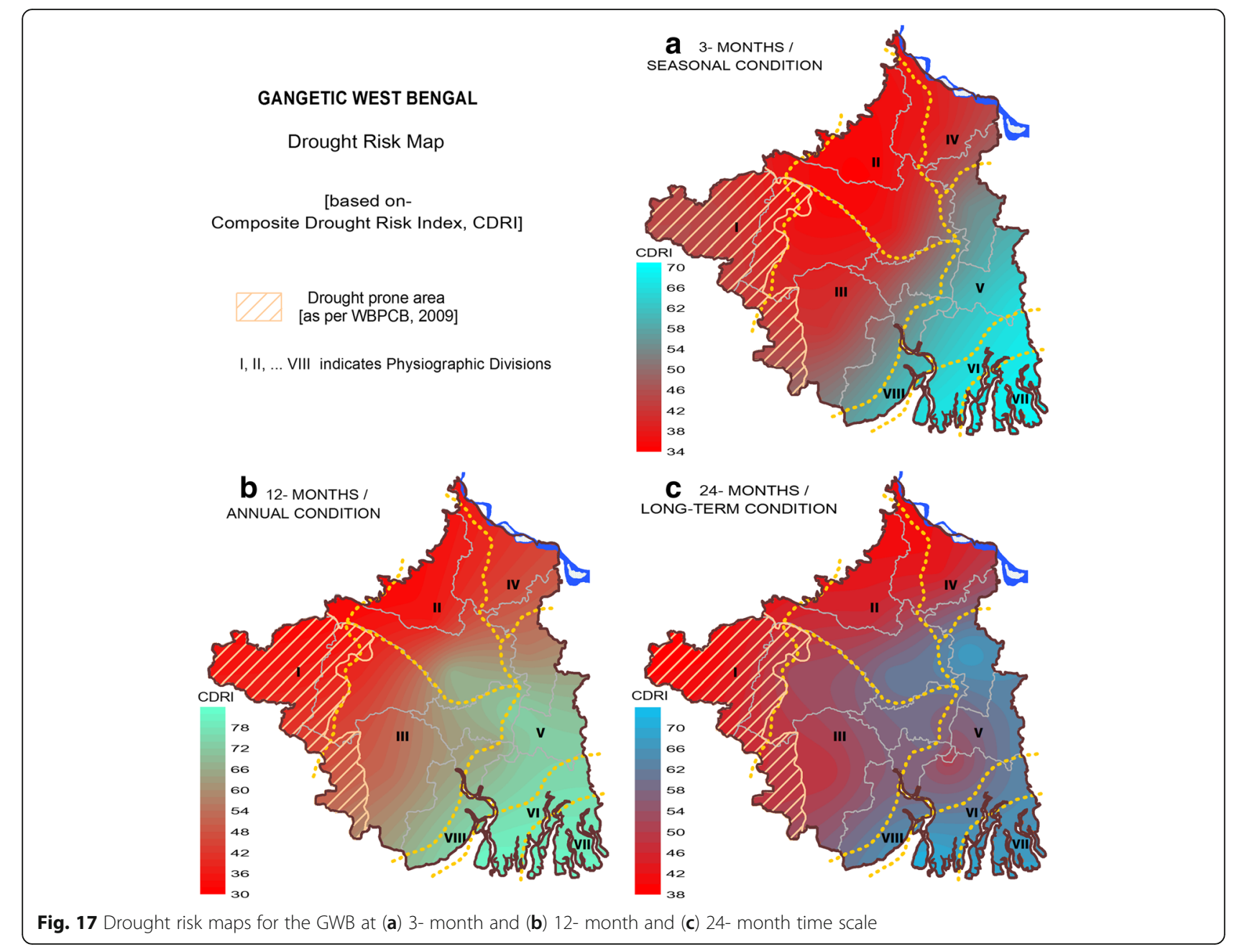

and mid monsoonal month of August. Study of Ghosh (2016) confirmed that, in the Birbhum district of the northern Rarh region there is a considerable decrease in monsoonal rainfall and increase in draught events in recent decades. Based on a single station (Kharagpur of the West Midnapore district) observation Lohar and Pal $(1995,1999)$ showed that mean monthly pre-monsoonal season precipitation has decreased while temperature has increased significantly the last decades of the twentieth century. In a nutshell, the increase of rainfall extremities and extension of aridity in the northern Rarh plain and moribund delta indicate potential threat to the rain-fed agriculture, food security and socio-economic vulnerability to drought in this region. Therefore, a more detailed study to explore the synergetic effects of the trend and pattern of other hydro-climatic variables is essential. However, the conclusion reached in this study can be an elementary step to improve the risk management strategy, review of agricultural practices and water use in this counterpart.

\section{Abbreviations}

CDRI: Composite Drought Risk Index; $D_{\triangleright}$ : Drought Duration; $D_{\triangleright} A$

(M): Average draught duration (month); $D_{D} l(M)$ : Observed most intense duration (month); $D_{D} L(M)$ : Observed longest drought duration (month); $F_{D}$ : Drought Frequency; Fj: Frequency of Drought Station; GWB: Gangetic West Bengal; ID: Drought Intensity; IMD: Indian Meteorological Department; $M_{D}$ : Drought Magnitude; $M_{D}$ : Mean Intensity of drought; MK test: Mann Kendall test; $\mathrm{Pl}_{\mathrm{D}}$ : Peak Intensity of drought; Pj: Drought Station Proportion; $S_{D}$ : Drought Severity; SPI: Standardized Precipitation Index; Tr: Return Period or Recurrence Interval; $T_{R D}$ : Rainfall Threshold/Critical Rainfall; WMO: World meteorological Organization

\section{Acknowledgements}

An earlier version of this article was presented at the 36th INCA International Congress on Cartography for Analysis and Management of Climate Change, held at the Department of Geography, Visva-Bharati University, Santiniketan, West Bengal, India in 2016 and the author likes to express his sincere thanks to Prof. Sutapa Mukhopadhyay of the Visva-Bharati University and Dr. Swades Pal of the University of Gour Banga, West Bengal, India for their reasonable suggestion during initial draft of the manuscript. In addition, the author is thankful to Mr. Debapriya Roy, Officer-in-Charge, Flood Meteorological Office, Jalpaiguri, West Bengal for his valuable information regarding available data bases and appropriate methodology to be applied for the study. The author is also appreciative to the Indian Meteorological Department for providing the data. Lastly my heartfelt thanks go to the anonymous reviewers for their constructive comments and suggestions to improve the manuscript. 


\section{Funding}

Sponsors or funding agency have no contribution to the present work.

\section{Availability of data and materials}

In this study only continuous time series rainfall data belonging to 12 meteorological stations (one representative station per district) of GWB (Fig. 1) for the period of 1901-2002 have been used.

\section{Author's contributions}

No other author had a role in the design of the study; in the collection, analyses, or interpretation of data; in the writing of the manuscript, and in the decision to publish the results. The author read and approved the final manuscript.

\section{Author's information}

The author is currently working as an Assistant Professor in the Department of Geography, Presidency University, Kolkata. He holds First Class First position in UG and PG from Visva-Bharati (A Central University of International Repute), Santiniketan, India and has a number of award and honour in his name. He has completed his Doctoral research in the fields of Hydrogeomorphology and is a life member of some geographical organization of great repute. His fields of expertise are Fluvial Geomorphology and Hydrometeorology.

\section{Competing interests}

The author declares that he has no competing interests.

\section{Publisher's Note}

Springer Nature remains neutral with regard to jurisdictional claims in published maps and institutional affiliations.

Received: 28 April 2018 Accepted: 28 December 2018

Published online: 21 January 2019

\section{References}

AD-GoWB: Agriculture Department, Govt. of West Bengal. 2009. State Agricultural Plan for West Bengal. http://www.rkvy.nic.in/static/SAP/WB/WB.PDF. Accessed 3 Nov 2015.

Amarasinghe, U.A., T. Shah, H. Turral, and B.K. Anand. 2007. India's water future to 2025-2050: Business-as-usual scenario and deviations, IWMI research report 123, 47. Colombo: International Water Management Institute http://www. iwmi.cgiar.org/Publications/IWMI_Research_Reports/PDF/PUB123/RR123.pdf. Accessed 11 Aug 2016

ARCC: African and Latin American Resilience to Climate Change. 2014. Design and Use of Composite Indices in Assessments of Climate Change Vulnerability and Resilience. http://www.ciesin.org/documents/Design_Use_ of_Composite_Indices.pdf. Accessed 2 July 2016.

Bagchi, K. 1944. The Ganges delta, 1-157. Calcutta: University of Calcutta Press.

Bagchi, K., and K.N. Mukerjee. 1983. Diagnostic survey of West Bengal, 17-19. Pantg Delta \& Rarh Bengal: Department of Geography, Calcutta University 42-58.

Bagchi, K., and K.N. Mukherjee. 1978. Diagnostic survey of deltaic West Bengal(s), 46-48. India: Department of Geography, Calcutta University, Government of West Bengal.

Bandyopadhyay, S., N.S. Kar, S. Das, and J. Sen. 2014. River systems and water resources of West Bengal: a review. Geological Society of India Special Publication 3: 63-84. https://doi.org/10.17491/cgsi\%2F2014\%2F62893.

Bates, B.C., Z.W. Kundzewicz, S. Wu, and S. Palutikof, eds. 2008. Climate change and water. Technical paper of the Intergovernmental Panel on Climate Change, 210. Geneva: IPCC Secretariat.

Biswas, K.R. 2001. Rivers of Bengal: a compilation. A series of 5 volume edited by West Bengal District gazetteers, higher education department. Kolkata: Govt of West Bengal.

Bonaccorso, B., I. Bordi, A. Cancielliere, G. Rossi, and A. Sutera. 2003. Spatial variability of drought: An analysis of the SPI in Sicily. Water Resources Management 17 (4): 273-296. https://doi.org/10.1023/A:1024716530289.

Burke, E.J., S.J. Brown, and N. Christidis. 2006. Modelling the recent evolution of global drought and projections for the twenty-first century with the Hadley Centre climate model. Journal of Hydrometeorology 7: 1113-1125. https://doi. org/10.1175/JHM544.1.
Chanda, B.N., and O.N. Dhar. 1975. Study of incidence of droughts in the Gangetic West Bengal. Proceedings of the National Academy of Sciences, India 42 (1): 22-33.

Cleveland, W.S. 2012a. Robust locally weighted regression and smoothing scatterplots. Journal of the American Statistical Association 74 (368): 829-836. https://doi.org/10.1080/01621459.1979.10481038.

Cleveland, W.S. 2012b. Graphs in scientific publications. The American Statistician 38 (4): 261-269. https://doi.org/10.1080/00031305.1984.10483223.

CRED: Centre for Research on the Epidemiology of Disasters. 2016. Country profile of natural disasters, EM-DAT: The International Disaster Database. http://www.emdat.be/country_profile/index.html. Accessed 8 Dec Nov 2016.

CRIDA: Central Research Institute for Dryland Agriculture. 2007. Perspective plan vision 2025, 52. Hyderabad: CRIDA.

Dai, A. 2011. Drought under global warming: A review. Wiley Interdisciplinary Reviews: Climate Change 2 (1): 45-65. https://doi.org/10.1002/wcc.81.

Damberg, L., and A. AghaKouchak. 2014. Global trends and patterns of drought from space. Theoretical and Applied Climatology 117 (3-4): 441-448. https:// doi.org/10.1007/s00704-013-1019-5.

DolW-GoWB: Department of Irrigation and Waterways, Govt. of West Bengal. 2014. Annual flood report for the year 2013, directorate of advance planning, 112. Kolkata: Project Evaluation \& Monitoring Cell.

Dong, G., H. Zhang, A. Moise, L. Hanson, P. Liang, and H. Ye. 2016. CMIP5 modelsimulated onset, duration and intensity of the Asian summer monsoon in current and future climate. Climate Dynamics 46 (1-2): 355-382. https://doi. org/10.1007/s00382-015-2588-z.

MoSPI-GoWB: Ministry of Statistics and Programme Implementation (MOSPI), Govt. of West Bengal (2012) Economic Review: 2011-12, Bureau of Applied Economics \& Statistics (BAE \& S), Kolkata, 305 p

Dracup, J.A., K.S. Lee, and E.G. Paulson Jr. 1980. On the definition of droughts. Water Resources Research 16 (2): 297-302. https://doi.org/10.1029/ WR016i002p00297.

Dupigny-Giroux, L.A. 2001. Towards characterizing and planning for drought in Vermont: Part-l: A climatological perspective. Journal of the American Water Resources Association 37 (3): 505-525. https://doi.org/10.1111/j.1752-1688. 2001.tb05489.x

Edwards, D.C., and T.B. McKee. 1997. Characteristics of 20th century drought in the United States at multiple time scales, Climatology report no. 97-2, 155. Fort Collins: Department of Atmospheric Science, Colorado State University.

Eze, J.N. 2018. Drought occurrences and its implications on the households in Yobe state, Nigeria. Geoenvironmental Disasters 5: 18. https://doi.org/10.1186/ s40677-018-0111-7.

Fontaine, R., A. Gramain, and J. Wittwer. 2009. Providing Care for an elderly parent: Interactions among siblings? Special Issue: 18th Annual European Workshop on Econometrics and Health Economics 18 (9): 1011-1029. https:// doi.org/10.1002/hec.1533.

Foster, J.E., M. McGillivray, and S. Seth. 2013. Composite indices: Rank robustness, statistical association, and redundancy. Econometric Reviews 32 (1): 35-56. https://doi.org/10.1080/07474938.2012.690647.

Francis, P.A., and S. Gadgil. 2010. Towards understanding the un usual Indian monsoon in 2009. Journal of Earth System Science 119 (4): 397-415. https:// doi.org/10.1007/s12040-010-0033-6.

Ghosh, K.G. 2016. Long range climatic variability over Birbhum District, West Bengal and their impact on Rainfed Aman crop in the context of climate change: adoption and mitigation. In Rural Health, women empowerment and agriculture: issues and challenges, Chap 21, ed. P.K. Chattopadhyay and D.S. Kushwaha, 1st ed., 277-298. India: New Delhi Publishers.

Ghosh, K.G. 2018. Analysis of rainfall trends and its spatial patterns during the last century over the Gangetic West Bengal, Eastern India. Journal of Geovisualization and Spatial Analysis 2: 15. https://doi.org/10.1007/s41651-018-0022-x.

Gupta, S.K., and R.D. Deshpande. 2004. Water for India in 2050: first-order assessment of available options. Current Science 86 (9): 1216-1224.

Guttman, N.B. 1998. Comparing the palmer drought index and the standardized precipitation index. Journal of the American Water Resources Association 34 (1): 113-121. https://doi.org/10.1111/j.1752-1688.1998.tb05964.x.

Haan, C.T., ed. 1977. Statistical methods in hydrology, 378. lowa, USA: The lowa State University Press.

Haldar, A.K., C.J. Thampi, and J. Sehgal. 1992. Soils of West Bengal for optimizing land use. NBSS publication 27b, Technical bulletin. Nagpur, India: National Bureau of Soil Survey and Land Use Planning.

Hayes, M.J., M.D. Svoboda, N. Wall, and M. Widhalm. 2011. The Lincoln declaration on drought indices: universal meteorological drought index 
recommended. Bulletin of the American Meteorological Society 92 (4): 485-488. https://doi.org/10.1175/2010BAMS3103.1.

Hayes, M.J., O.V. Wilhelmi, and C.L. Knutson. 2004. Reducing drought risk: bridging theory and practice. Natural Hazards Review 5 (2): 106-113. https://doi.org/10. 1061/(ASCE)1527-6988(2004)5:2(106).

Hosseinizadeh, A., H. SeyedKaboli, H. Zareie, A. Akhondali, and B. Farjad. 2015. Impact of climate change on the severity, duration, and frequency of drought in a semi-arid agricultural basin. Geoenvironmental Disasters 2: 23. https://doi.org/10.1186/s40677-015-0031-8.

INCCA: Indian Network for Climate Change Assessment. 2010. Climate Change and India: A 4x4 Assessment a Sectoral and Regional Analysis for 2030s, 164 Ministry of Environment \& Forests Government of India www.moef.nic.in/ downloads/public-information/fin-rpt-incca.pdf. Accessed 13 May 2016.

IPCC: Intergovernmental Panel of Climate Change. 2013. Working group I contribution to the IPCC Fifth Assessment Report Climate Change 2013: The physical science basis-summary for policymakers. Stockholm: Intergovernmental Panel of Climate Change.

IPCC: Intergovernmental Panel on Climate Change. 2007. Climate change 2007: The physical science basis. In Contribution of working group I to the fourth assessment report of the intergovernmental panel on climate change, ed. S. Solomon, D. Quin, M. Manning, X. Chen, M. Marquis, K.B. Averyt, H.L. Tignor, and M. Miller, 1-996. Cambridge: Cambridge University Press.

Islam, S., ed. 2006. Encyclopedia of Bengal. Dhaka: Asiatic Society of Bangladesh, Asiatic Civil Military Press.

Ji, L., and A. Peters. 2003. Assessing vegetation response to drought in the northern Great Plains using vegetation and drought indices. Remote Sensing of Environment 87 (1): 85-98. https://doi.org/10.1016/S0034-4257(03)00174-3.

Kamble, M.V., K. Ghosh, M. Rajeevan, and R.P. Samui. 2010. Drought monitoring over India through normalized difference vegetation index (NDVI). Mausam 61: 537-546.

Kar, B., J. Saha, and J.D. Saha. 2012. Analysis of meteorological drought: the scenario of West Bengal. Indian Journal of Spatial Science 3 (2): 1-11.

Kendall, M.G. 1975. Rank correlation methods. London, UK: Charles Griffin.

Keyantash, J.A., and J.A. Dracup. 2002. The quantification of drought: an evaluation of drought indices. Bulletin of the American Meteorological Society 83 (8): 1167-1180. https://doi.org/10.1175/1520-0477-83.8.1167.

Kogan, F.N. 2000. Contribution of remote sensing to drought early warning. In Early warning systems for drought preparedness and drought management, Proceedings of an expert group meeting held on Warning Systems for Drought Preparedness and Drought Management, ed. D.A. Wilhite, M.V.K Sivakumar, and D.A. Wood, 75-87. World Meteorological Organization, Geneva, Switzerland.

Lal, M. 2003. Global climate change: India's monsoon and its variability. Journal of Environmental Studies and Policy 6: 1-34.

Li, Y.J., X.D. Zheng, F. Lu, and J. Ma. 2012. Analysis of drought evolvement characteristics based on standardized precipitation index in the Huaihe River basin. Procedia Engineering 28: 434-437. https://doi.org/10.1016/j.proeng. 2012.01.746.

Lohar, D., and B. Pal. 1995. The effect of irrigation on pre-monsoon season precipitation over South West Bengal, India. Journal of Climate 8: 2567-2570. https://doi.org/10.1175/1520-0442(1995)008<2567:TEOIOP>2.0.CO;2.

Lohar, D., and B. Pal. 1999. Effect of change in land-use on pre-monsoon season climate over South West Bengal, India, Advanced Technologies in Meteorology, 102-105. Tata McGraw-Hill Publishing Company Ltd. New Delhi

Mallya, G., V. Mishra, D. Niyogi, S. Tripathi, and R.S. Govindaraju. 2016. Trends and variability of droughts over the Indian monsoon region. Weather and Climate Extremes 12 (June): 43-68. https://doi.org/10.1016/j.wace.2016.01.002.

Mann, H.B. 1945. Nonparametric tests against trend. Econometrica 13 (3): 245-259. https://doi.org/10.2307/1907187.

McKee, T.B., N.J. Doesken, and J. Kleist. 1993. The relation of drought frequency and duration to time scales, Proceeding of the eight conference on applied climatology. 17-22 January, Anaheim, California, 179-184. Boston, Massachusetts: American Meteorological Society.

McKee, T.B., N.J. Doesken, and J. Kleist. 1995. Drought monitoring with multiple time scales, Proceeding of the ninth conference on applied climatology. 1520 January, Dallas, Texas, 233-236. Boston, Massachusetts: American Meteorological Society.

Mishra, A.K., and V.P. Singh. 2010. A review of drought concepts. Journal of Hydrology 391 (1-2): 202-216. https://doi.org/10.1016/j.jhydrol.2010.07.012.

Mishra, A.K., and V.P. Singh. 2011. Drought modeling-a review. Journal of Hydrology 403 (1-2): 157-175. https://doi.org/10.1016/j.jhydrol.2011.03.049.
Mishra, S. 2010. Abar Kharar Kabale Paschim Banga (in Bengali). Saar Samachar 48 (3): 11-30.

Mishra, S.S., R. Nagarajan. 2011. Drought assessment in Tel watershed: an integrated approach using run analysis and SPI. IEEE Earthzine 1/8-8/8. https://earthzine.org/drought-assessment-in-tel-watershed-an-integratedapproach-using-run-analysis-and-spi/ . Accessed 14th May 2016

Morid, S., V. Smakhtin, and M. Moghaddasi. 2006. Comparison of seven meteorological indices for drought monitoring in Iran. International Journal of Climatology 26 (7): 971-985. https://doi.org/10.1002/joc.1264.

Nath, S.K., D. Roy, and S.K.K. Thingbaijam. 2008. Disaster mitigation and management for West Bengal, India-an appraisal. Current Science 94 (4): 858-864.

NRC: National Research Council. 2010. Adapting to the impacts of climate change: America's climate choices. Washington, DC: National Academies Press.

O'Brien, K., R. Leichenko, U. Kelkar, H. Venema, et al. 2004. Mapping vulnerability to multiple stressors: Climate change and globalization in India. Global Environmental Change 14 (4): 303-313. https://doi.org/10.1016/j.gloenvcha. 2004.01.001.

Oladipo, E.O. 1985. A comparative performance analysis of three meteorological drought indices. International Journal of Climatology 5 (6): 655-664. https:// doi.org/10.1002/joc.3370050607.

Pai, D.S., L. Sridhar, P. Guhathakurta, and H.R. Hatwar. 2011. District-wide drought climatology of the southwest monsoon season over India based on standardized precipitation index (SPI). Natural Hazards 59 (3): 1797-1813. https://doi.org/10.1007/s11069-011-9867-8.

Palchaudhuri, M., and S. Biswas. 2013. Analysis of meteorological drought using standardized precipitation index-a case study of Puruliya district, West Bengal, India. International Journal of Environmental and Ecological Engineering 7 (3): 119-126 https://waset.org/publications/9996966/analysis-ofmeteorological-drought-using-standardized-precipitation-index-a-case-studyof-puruliya-district-west-bengal-india.

Parthasarathy, B., N.A. Sontakke, A.A. Monot, and D.R. Kothawale. 1987. Droughts/ floods in the summer monsoon season over different meteorological subdivisions of India for the period 1871-1984. International Journal of Climatology 7 (1): 57-70. https://doi.org/10.1002/joc.3370070106.

Potop, V., C. Boroneant, M. Mozny, P. Stepanek, and P. Skalak. 2014. Observed spatiotemporal characteristics of drought on various time scales over the Czech Republic. Theoretical and Applied Climatology 115: 563-581. https://doi. org/10.1007/s00704-013-0908-y.

Potop, V., M. Mozny, and J. Soukup. 2012. Drought evolution at various time scales in the lowland regions and their impact on vegetable crops in the Czech Republic. Agricultural and Forest Meteorology 156: 121-133. https://doi. org/10.1016/j.agrformet.2012.01.002.

Rachchh, R., and N. Bhatt. 2014. Monitoring of drought event by standardized precipitation index (SPI) in Rajkot district, Gujarat, India. International Journal of Engineering Development and Research 2 (1): 917-921.

Roy, S., and M. Mukhopadhyay. 2012. Nor'wester-a cognitive study for environmental appraisal, 104. Germany: Lambert Academic Publishing.

RPAPCC: Regional Policy Action Platform on Climate Change. 2012. Climate Change Policy Paper I-IV. http://www.wwfindia.org/?7560/regional-policy-actionplatform-on-climate-change-rpapcc-policy-paper. Accessed 19 Nov 2015.

Sen, P.K. 1968. Estimates of the regression coefficient based on Kendall's tau. Journal of the American Statistical Association 63 (324): 1379-1389. https://doi. org/10.1080/01621459.1968.10480934.

Sikka, D.R. 2003. Evaluation of monitoring and forecasting of summer monsoon over India and a review of monsoon drought of 2002, Proceedings of the National Science Academy of India Section A69, 479-504.

Sonmez, F.K., A.U. Komuscu, A. Erkan, and E. Turgu. 2005. An analysis of spatial and temporal dimension of drought vulnerability in Turkey using the standardized precipitation index. Natural Hazards 35 (2): 243-264. https://doi. org/10.1007/s11069-004-5704-7.

Spinoni, J., G. Naumann, H. Carrao, P. Barbosa, and J. Vogt. 2014. World drought frequency, duration, and severity for 1951-2010. International Journal of Climatology 34 (8): 2792-2804. https://doi.org/10.1002/joc.3875.

Thomas, T., P.C. Nayak, and N.C. Ghosh. 2015. Spatiotemporal analysis of drought characteristics in the bundelkhand region of central india using the standardized precipitation index. Journal of Hydrologic Engineering 20 (11): 05015004-1-05015004-12. https://doi.org/10.1061/(ASCE)HE.1943-5584. 0001189.

Thompson, S. 1999. Hydrology for water management, 476. Rotterdam, The Netherlands: AA Balkema Publ. 
Trenberth, K.E., Jones, P.D., Ambenje, P., Bojariu, R., Easterling, D., Klein Tank, A., Parker, D., Rahimzadeh, F., Renwick, J.A., Rusticucci, M., Solden, B., and Zhai, P. 2007. Observations: Surface and atmospheric Climate Change, Climate Change 2007: The Physical Science Basis. Contribution of Working Group/to the Fourth Assessment Report of the Intergovernmental Panel on Climate Change. Cambridge University Press, Cambridge, UK and New York, NY, pp 235-336

Trenberth, K.E., A. Dai, G. Schrier, P.D. Jones, J. Barichivich, K.R. Briffa, and J. Sheffield. 2014. Global warming and changes in drought. Nature Climate Change 4: 17-22. https://doi.org/10.1038/nclimate2067.

Tsubo, M., S. Fikai, J. Basnayake, and M. Ouk. 2009. Frequency of occurrence of various drought types and its impact on performance of photoperiodsensitive and insensitive rice genotypes in rain-fed lowland conditions in Cambodia. Field Crops Research 113 (3): 287-296. https://doi.org/10.1016/j.fcr. 2009.06.006.

Wang, Q.F., J.J. Wu, T.J. Lei, B. He, Z.T. Wu, M. Liu, X.Y. Mo, G.P. Geng, X.H. Li, H.K. Zhou, et al. 2014. Temporal-spatial characteristics of severe drought events and their impact on agriculture on a global scale. Quaternary International 349: 10-21. https://doi.org/10.1016/j.quaint.2014.06.021.

WBPCB: West Bengal Pollution Control Board. 2009. A state of environment report: water resource and its quality in West Bengal, Kolkata, 352.

WBSAPCC: West Bengal State Action Plan on Climate Change. 2010. Govt. of West Bengal, India. http://moef.nic.in/downloads/public-information/WestBengal-SAPCC.pdf. Accessed 30 Nov 2013.

Wilhite, D.A. 2003. Moving toward drought risk management: The need for global strategy. https://www.researchgate.net/profile/Donald_Wilhite/ publication/265042105_Moving_Toward_Drought_Risk_Management_The_ Need_for_a_Global_Strategy/links/558952ce08ae273b2875f7ea.pdf. Accessed 13 June 2016.

Wilhite, D.A., and M.H. Glantz. 1985. Understanding the drought phenomenon: The role of definitions. Water International 10 (3): 111-120. https://doi.org/10. 1080/02508068508686328.

WMO: World Meteorological Organization. 2012. Standardized Precipitation Index User Guide (Svoboda M, Hayes M, Wood D). WMO-No. 1090, Geneva. http:// www.wamis.org/agm/pubs/SPI/WMO_1090_EN.pdf. Accessed 23 Nov 2015.

Wu, M., Y. Chen, H. Wang, and G. Sun. 2015. Characteristics of meteorological disasters and their impacts on the agricultural ecosystems in the northwest of China: A case study in Xinjiang. Geoenvironmental Disasters 2: 3. https:// doi.org/10.1186/s40677-015-0015-8.

Zargar, A., R. Sadiq, B. Naser, and F.I. Khan. 2011. A review of drought indices. Environmental Reviews 19: 333-349. https://doi.org/10.1139/a11-013.

\section{Submit your manuscript to a SpringerOpen ${ }^{\circ}$ journal and benefit from:}

- Convenient online submission

- Rigorous peer review

- Open access: articles freely available online

- High visibility within the field

- Retaining the copyright to your article

Submit your next manuscript at $\boldsymbol{\nabla}$ springeropen.com 